\title{
複合地盤の改良範囲および改良強度が 杭の地震時挙動に及ぼす影響
}

\author{
冨澤 幸一 1 三浦 清一2・渡辺 忠朋3 \\ 1正会員 寒地土木研究所 寒地地盤チーム（ \\ E-mail:ko-tomsw@ceri.go.jp \\ 2 フェロー会員 北海道大学大学院 工学研究科 ( $\overline{0} 060-8628$ 札幌市北区北十三条西八丁目) \\ E-mail:s-miura@eng.hokudai.ac.jp \\ 3正会員＼cjkstart北武コンサルタント（ $\bar{T} 062-0020$ 札幌市豊平区月寒中央通七丁目） \\ E-mail:chuho@hokubu-c.co.jp
}

\begin{abstract}
軟弱地盤中の杭の水平抵抗の増加を図るため杭周辺に複合地盤を形成する工法において, その地震時挙 動を検討した. 2次元有限要素法による動的非線形解析の結果, 複合地盤を施すことで地震時に杭水平変位, 杭ひずみおよび地盤変形が抑制された. その傾向はレベル1地震動のみでなくレベル2地震動でも同様であ った. また, 複合地盤の改良強度および改良範囲を杭特性長 $1 / \beta$ を指標に種々に変化させた検討の結果, 特 に杭の応答変位やひずみに改良深さが大きな影響を及ぼすことが明らかとなった. 地震時の地盤変形は改 良深さの増加と伴に減少し, 杭と一体化するように挙動した. これらを踏まえ, 複合地盤における杭の耐震 照査フローを策定し, 耐震上の課題を整理した。
\end{abstract}

Key Words : piles, ground improvement, seismic design, dynamic finite element method

\section{1. はじめに}

軟弱地盤に施工する杭の頭部周辺に深層混合処理工法 による複合地盤を形成する手法を研究し実用化した ${ }^{1) 22}$. 本手法は，複合地盤のせん断強度を杭の水平抵抗に反映 させることで杭本数・下部工躯体を縮小させ，建設コス 卜縮減が可能となる.

本手法では，静的荷重における工学的な検討に基づき， 杭周辺の複合地盤の改良範囲および改良強度が設定され る. 寸なわち, 杭の水平地盤反力を複合地盤のせん断強 度 $S$ から算定し，必要な複合地盤領域を杭特性長 $1 / \beta$ を 指標に杭水平抵抗の及ぶ範囲に設定する.この手法の妥 当性は, 現場における実杭の静的水平載荷試験および静 的有限要素法解析により検証している ${ }^{1), 2)}$.

一方，これまでこの工法に対する杭の耐震設計は，主 として地盤をバネにモデル化し, 地震の影響を慣性力と して作用させる方法で実施してきた. しかし，地震時に おける複合地盤中の杭挙動は複雑であり, 地震動レベル や地盤性状により種々異なることが予想される。これま でに各機関で，杭と改良体を併用した複合基礎に関寸る

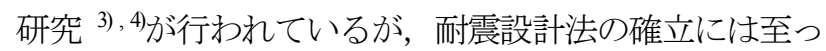

ていない．また，被災した杭の而震補強工法として杭周

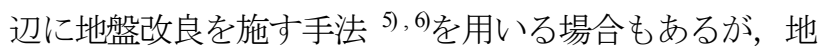
震動レベルに応じた適正な改良範囲や改良強度の設定法 は体系化されているとは言い難い.

そのため本報では, 複合地盤中の杭の而震設計法に関 する基礎資料を得る目的で, 実現場をモデルに, 地震動レ ベルの変化や複合地盤の改良範囲および改良強度が杭の 地震時挙動に与える影響を検討した. 杭の地震時挙動の 検討には実験的手法もあるが, 複合地盤中の杭を縮小模 型などでモデル化することは困難である. そこで, 地盤一 杭一構造物を一体として動的応答解析を行う事例》, 8 , ,9) 一般的であることを考慮し, 本検討では2次元有限要素法 による動的非線形解析を実施した.

ここでは, 改良範囲および改良強度を工学的に設定し た静的荷重の設計手法を踏まえ, 複合地盤における杭の 地震時挙動を以下の手順で検討した。

(1) 複合地盤の有無に注目したレベル1, レベル2地震動に おける杭水平変位,杭ひずみおよび地盤変形の検討.

(2)複合地盤のパラメータ (改良幅,改良深さ,改良強度) を種々に変化させた, 杭水平変位, 杭ひずみおよび地 盤変形の相違の検証. 


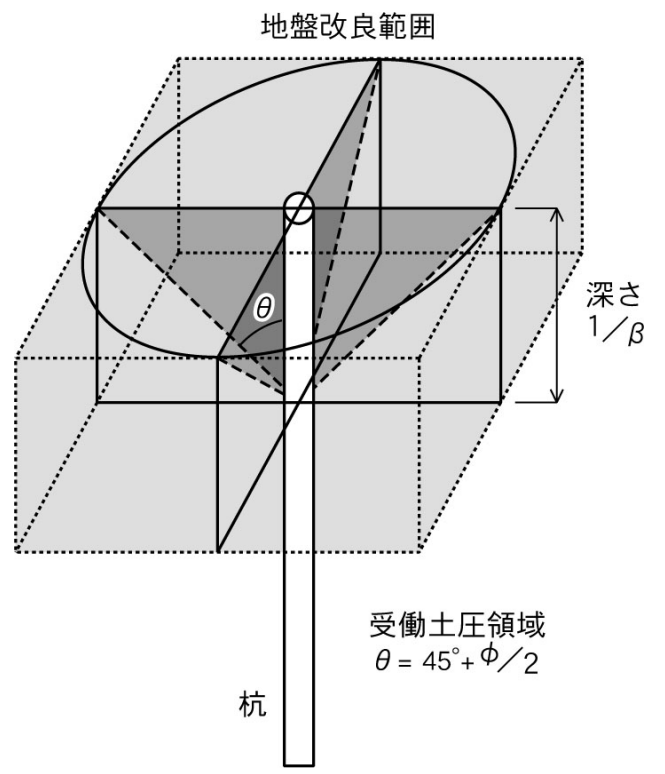

図-1＼cjkstart杭に対する複合地盤の改良範囲の設定

(3)一連の解析結果に基づく, 複合地盤における杭の而震 照査フローの策定および留意点の整理.

\section{2. 複合地盤における杭の静的設計手法}

静的荷重における複合地盤中の杭の設計手法は，概ね 以下のように整理される1),2).

\section{（1）杭周辺の複合地盤の改良範囲}

杭周辺の複合地盤の改良範囲は, 土の極限状態の釣り 合いを考慮することで受働破壊の領域が設定される.つ まり, 必要な改良範囲を杭水平抵抗の影響領域と考えれ ば,杭特性長 $1 / \beta$ から受働すべり面の勾配 $\theta=\left(45^{\circ}+\phi / 2\right)$ ( $\phi$ : 土のせん断抵抗角)で立ち上げた逆円錐形を含む 図-1に示す四角柱を設定することができる.これは,モー ル・クーロンの破壊基準や極限地盤反力法（Broms ${ }^{10)}$ ， Reese (1) $^{11}$ ) を工学的根拠とする. その際,この工法では 複合地盤中の杭は群杭としての平均的な水平地盤反力を 確保するため, 改良率 $a_{p}$ は接円の $78.5 \%$ 以上を適用範囲 とするのが望ましい.

\section{(2)複合地盤中の杭の静的水平地盤反力}

杭の水平抵抗は，作用荷重に対する水平地盤反力とし て扱うことで杭の諸元や地盤性状に応じて式(1) ${ }^{12)}$ で算定 される.つまり，弾性地盤反力法では杭の水平抵抗の設 計は水平地盤反力係数 $k$ により設定される. その結果, 式(1)より, 複合地盤に施工する杭の水平地盤反力係数 $k$ は, 複合地盤の変形係数Eにより算定することができる.

$$
k=\frac{1}{0.3} \alpha E \cdot\left(\frac{\sqrt{D / \beta}}{0.3}\right)^{-3 / 4}
$$

ここに, $k$ : 杭の水平地盤反力係数 $\left(\mathrm{kN} / \mathrm{m}^{3}\right), E$ : 複合地盤 の变形係数 $\left(\mathrm{kN} / \mathrm{m}^{2}\right), \alpha$ : 水平地盤反力推定に用いる係数, $D:$ 杭径 $(\mathrm{m}), \beta$ : 杭特性值 $\left(\mathrm{m}^{-1}\right)$ である.

一方，深層混合処理工法で地盤改良を行う場合，所要 強度の改良柱を杭周辺に打設し複合地盤を形成する. そ の際, 複合地盤のせん断強度 $S$ は改良柱体の強度 $S_{p}$ と原 地盤強度 $S_{0}$ を改良率 $a_{p}$ に従い合成した式(2) ${ }^{13), 14)}$ で算定さ れる.

$$
\begin{gathered}
S=S_{p} \cdot a_{p}+\alpha_{s} \cdot S_{0}\left(1-a_{p}\right) \\
S_{p}=q_{u p} / 2, \quad S_{0}=q_{u 0} / 2, a_{p}=A_{p} / A
\end{gathered}
$$

ここに, $S$ : 複合地盤のせん断強度 $\left(\mathrm{kN} / \mathrm{m}^{2}\right), S_{p}$ : 改良柱体の せん断強度 $\left(\mathrm{kN} / \mathrm{m}^{2}\right), \alpha_{S}$ : 破壊ひずみに対する原地盤強度 の低減率, $S_{0}$ : 原地盤のせん断強度, $a_{p}$ : 地盤改良率, $q_{v p}$ : 改良柱体の一軸圧縮強度 $\left(\mathrm{kN} / \mathrm{m}^{2}\right), q_{\imath 0}$ : 原地盤の一軸圧縮 強度 $\left(\mathrm{kN} / \mathrm{m}^{2}\right), A_{p}$ : 改良柱体断面積 $\left(\mathrm{m}^{2}\right), A$ : 改良柱体一本当 りの分布面積 $\left(\mathrm{m}^{2}\right)$ である. 深層混合処理工法では改良柱体 の一軸圧縮強度 $q_{v p}$ は, 一般的に設計基準強度で $q_{v p}=200 \sim$ $500 \mathrm{kN} / \mathrm{m}^{2}$ 程度としている.

複合地盤中の杭の水平地盤反力を適正に設定するため には, 地盤改良により増加した地盤のせん断強度 $S$ の効 果を変形係数 $E$ の増加の度合として評価する必要があ る. 深層混合処理工法では, 改良柱体のせん断強度 $S_{p}$ は式 (2)に示すように改良柱体の一軸圧縮強度 $q_{v p}$ と $S_{p}=q_{v p} / 2$ の関係にある. また, 改良柱体の一軸圧縮強度 $q_{v p}$ と変形 係数 $E_{p}$ は比例的な関係にあることが広く知られており, 粘性土系地盤を改良した場合に $E_{p}=100 q_{v p}{ }^{13)}$ の関係式が提 案されている.

つまり, 複合地盤の変形係数 $E$ はせん断強度 $S$ の増加 と同等と扱うことができ, 複合地盤の変形係数 $E$ は, 式(3) に示すように改良柱体の変形係数 $E_{p}$ 亡原地盤の変形係 数 $E_{0}$ の改良率 $a_{p}$ で合成した和によって算定が可能と考 えられる.

$$
E=E_{p} \cdot a_{p}+\alpha_{s} \cdot E_{0}\left(1-a_{p}\right)
$$

ここに, $E_{p}$ : 改良柱体の変形係数 $\left(\mathrm{kN} / \mathrm{m}^{2}\right), E_{0}$ : 原地盤の 変形係数 $\left(\mathrm{kN} / \mathrm{m}^{2}\right)$ である.

この手法より, 複合地盤の増加したせん断強度を杭の 水平地盤反力として反映することで, 静的荷重において, より大きな杭の水平抵抗が確保される.

これまでの軟弱地盤における橋台基礎杭の設計シミュ 

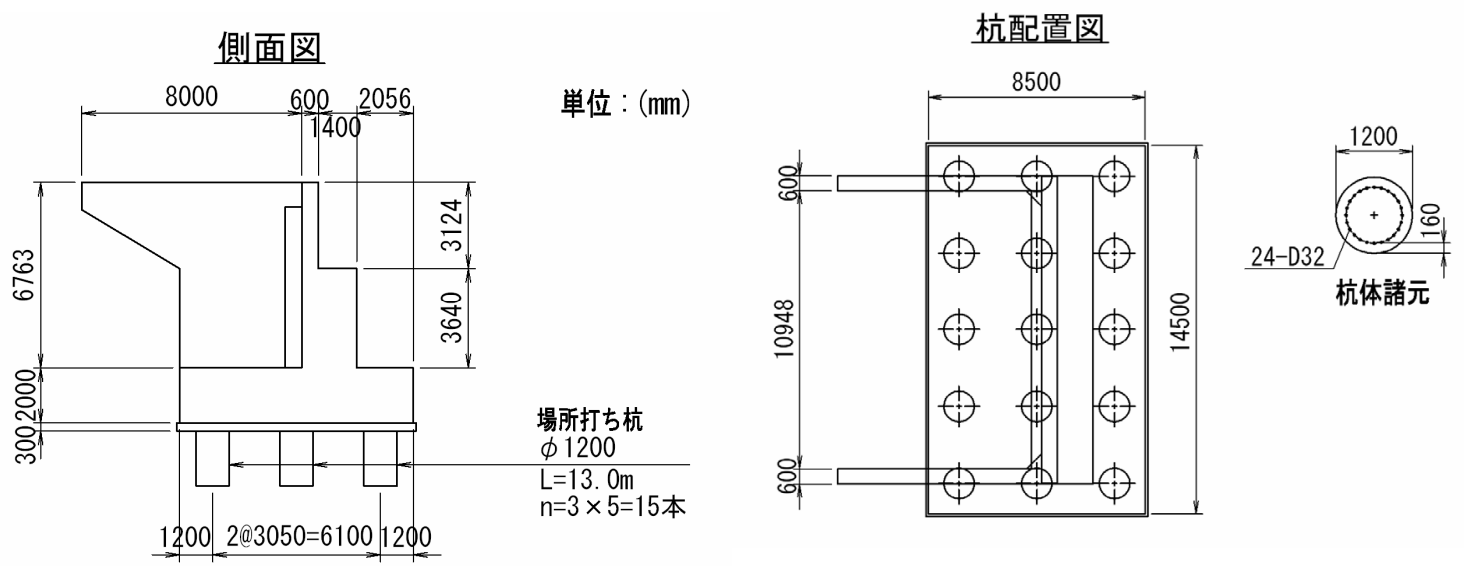

図-2 構造物基礎の諸元

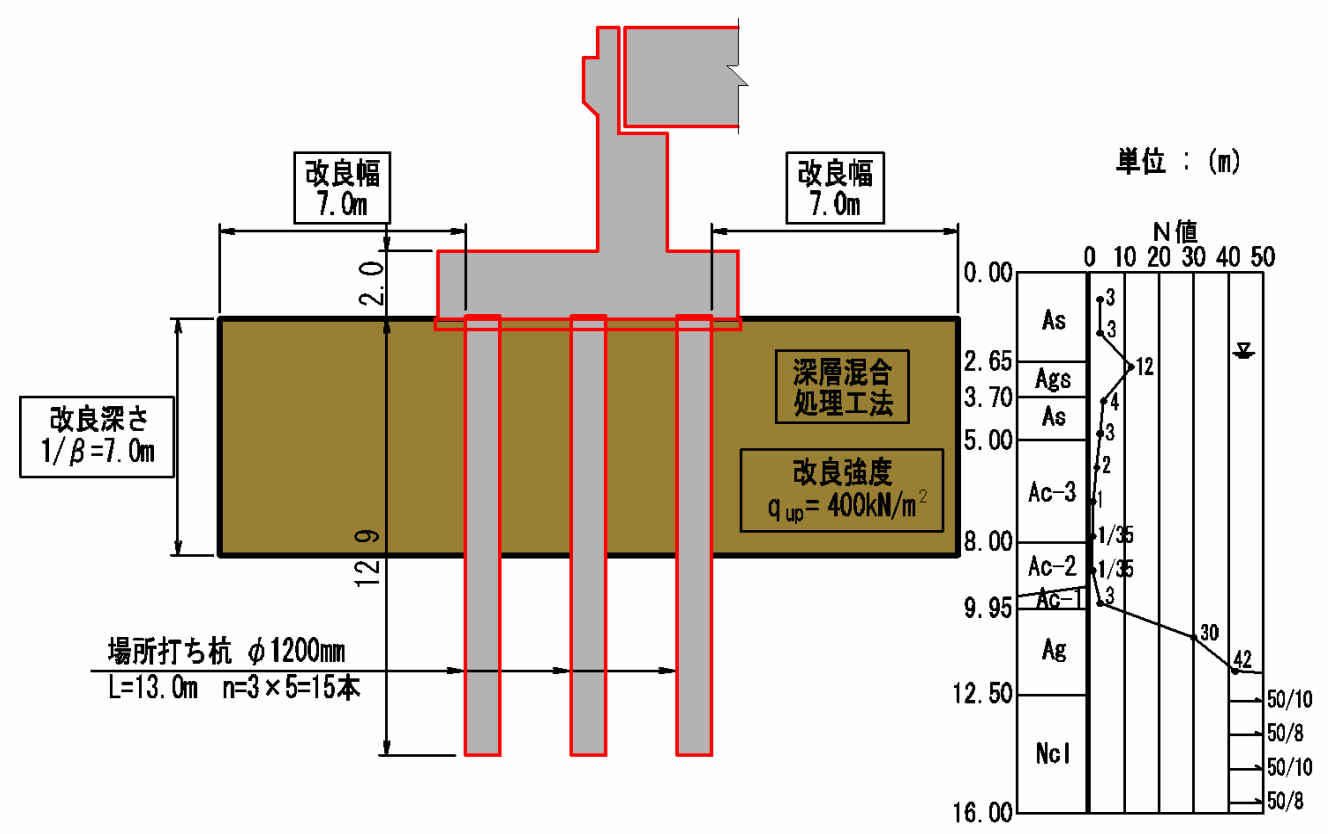

図-3 橋台および地盤柱状

レーション（15 現場）では, 複合地盤を施さない従来の 設計に対し, 杭周辺に複合地盤を形成することで建設コ ストが 20〜 50\%程度縮減できることを確認している ${ }^{1), 2)}$.

ただし, 本手法は静的荷重において成立するが, 地震時 に複合地盤が杭に対し反力体の効果を発揮する確証はな い. また, 地震時の杭の挙動は, 地盤と構造物の相互作用 による応答であるため, 必ずしも慣性力のみを考慮した 振動形態が卓越するとは限らない.

そこで本報では，これらの問題を検討するため道路橋 の実橋台をモデルに，地震時における複合地盤中の杭挙 動を解析した. 言うまでもなく，地盤性状は現場により 種々異なり，一現場の検討成果が定量的な一般解とはな らない.ただし，複合地盤の存在が杭の地震時挙動に及 ぼす影響を的確に把握することが重要である.

\section{3. 実現場の対象モデル}

複合地盤中の杭の地震時挙動の検討を実施した現場モ デルは, 実際に杭周辺に複合地盤を施工する工法を採用 した軟弱地盤上の橋台基礎とした. 図-2 に構造物基礎の 諸元, 図-3に橋台および地盤柱状を示す.橋台位置の地盤 柱状は, 上層部 $5.0 \mathrm{~m}$ に液状化が想定されるゆるい砂層, 下層部約 $5.0 \mathrm{~m}$ に軟弱なシルトが介在し, 支持層を深さ $12.5 \mathrm{~m}$ 以深の頁岩基盤としている. 杭は場所打ち杭(杭径 $D=1200 \mathrm{~mm}$, 杭長 $L=13 \mathrm{~m}$, 杭配列 $n=3 \times 5=15$ 本)を選定し ている. 杭周辺には深層混合処理工法（CDMセメントス ラリー系） ${ }^{13)}$ による複合地盤を形成している. 複合地盤 の改良範囲は前節の静的設計手法に従い, 改良深さを杭 特性長 $1 / \beta=7.0 \mathrm{~m}$ とし, 改良幅は地盤のせん断抵抗角 $\phi=0$ 


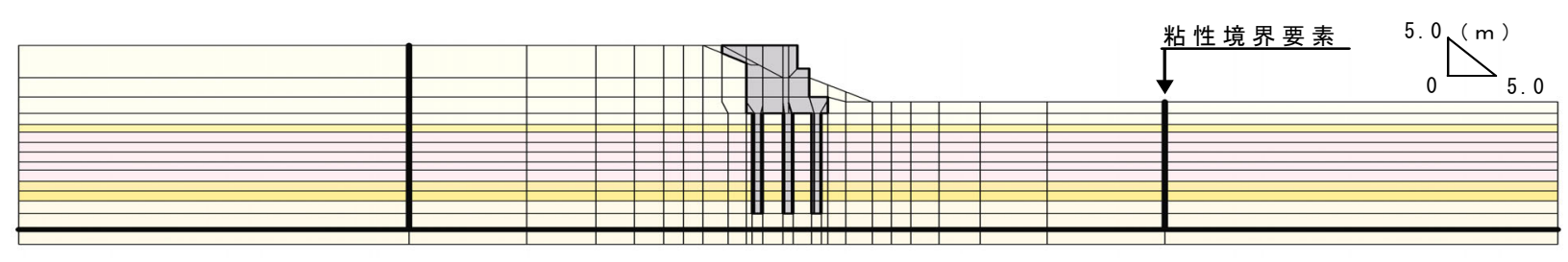

(a)2 次元モデル全体図

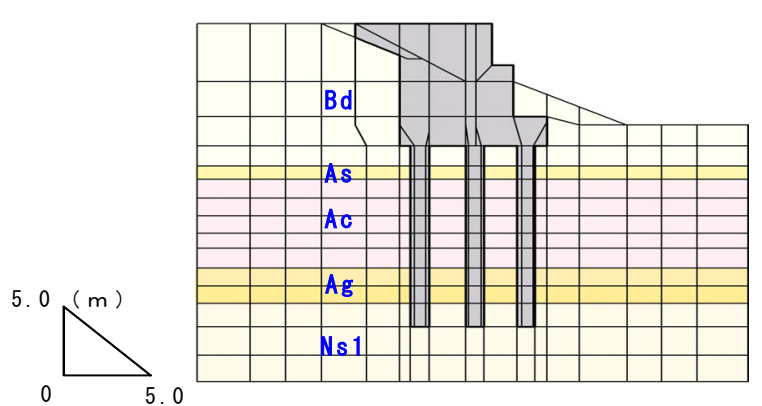

(b)橋台近傍拡大図

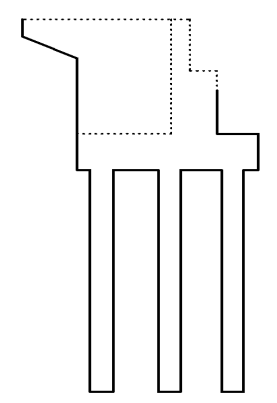

(c)ジョイント要素

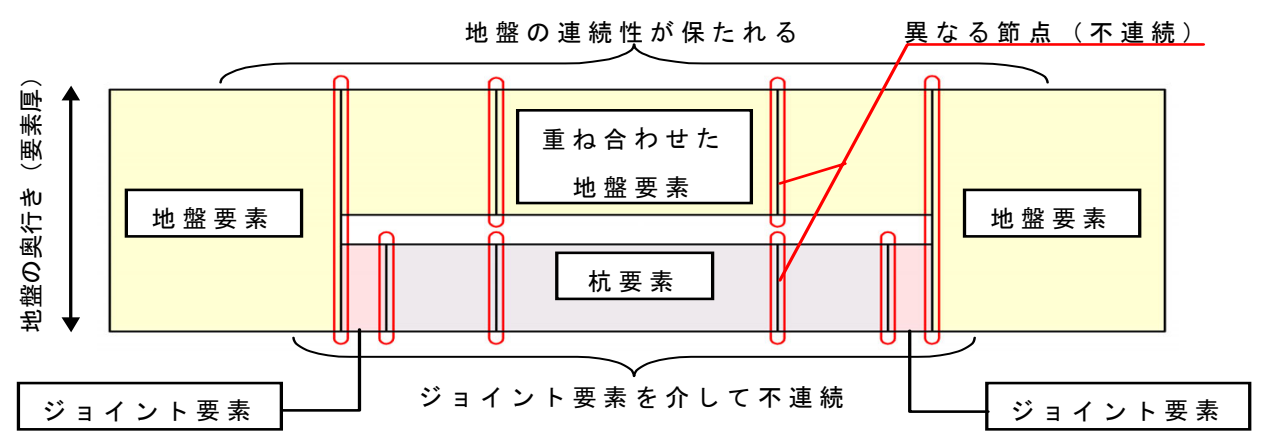

(d)杭要素と地盤要素の重祆合わせ概念図

図-4２次元動的非線形有限要素モデル

とし受働土圧領域に相当する改良幅=7.0m とした. 複合地 盤の改良率 $a_{p}=78.5 \%$, 改良体の一軸圧縮強度 $q_{u p}=400 \mathrm{kN} / \mathrm{m}^{2}$ である.この設計手法による複合地盤中の杭 水平地盤反力係数 $k$ は未改良の原地盤に対し 50 倍程度 に相当する. その結果, 複合地盤を杭周辺に施すことで大 きな水平抵抗が確保され, 当該現場では杭列数を 5 列か ら 3列に減じている. なお, 杭断面には異形鉄筋 D32 24 本配置し鉄筋中心までのかぶり厚を $160 \mathrm{~mm}$ としている. 支承位置における常時設計の死活荷重反力は総計 2700kNである.

橋台基礎を解析モデルとしたのは，橋台は背面土を有 するため橋軸方向に対しては非対称となり，杭と地盤の 動的挙動が顕著に表れると判断したことによる.

\section{4. 解析モデルと用いた構成則}

本工法では, 軟弱地盤に対し杭頭部に剛性の大きな人 工地盤を形成するため杭の而震性が不明瞭である. そこ で, 複合地盤中の杭の地震時挙動を非線形有限要素法に より検討した.

\section{(1) 2次元動的非線形有限要素モデル}

杭の地震時挙動の解析には 3 次元有限要素法が有効で あるが, 多くのケース数を解析するには多大な時間を要 寸る. そのため, 適正な奥行き幅を設定することで 2 次元 解析によっても複合地盤中の杭の地震時挙動の考察が可 能と判断した ${ }^{15,16,17) .}$

上記で設定した現場モデルにおいて杭周辺に複合地盤 を施さない状態で, 3 次元動的非線形有限要素法解析と 奥行き幅を 3 種類（フーチング奥行きの 1.0 倍, 1.5 倍, 3.0 倍）に変化させた 2 次元動的非線形有限要素法解析を実 施し,解析結果を対比した. その結果, 3 次元解析と 2 次元 解析で得られた杭の並進・回転応答および変形性状の相 関が最も高いのはフーチング幅を奥行きとしたものであ った ${ }^{18}$. そのため, 以降の動的検討は奥行き幅をフーチン グ幅に設定した 2 次元非線形有限要素法解析によること とした.

2 次元動的非線形有限要素法解析に用いたモデルを 図-4 に示す，モデルでは橋台および杭は 8 節点平面応 力要素, 地艋は 8 節点平面ひずみ要素を用いてモデル化 し, 要素分割幅は 3 次元動的非線形有限要素法のモデル 
表-1 有限要素法解析における地盤の入力物性值

\begin{tabular}{|c|c|c|c|c|c|c|c|c|c|}
\hline 記号 & 土質 & $\begin{array}{c}\text { 層厚 } \\
(\mathrm{m})\end{array}$ & $N$ 值 & $\begin{array}{c}\text { 単位体積 } \\
\text { 重量 } \\
\rho \\
\left(\mathrm{kN} / \mathrm{m}^{3}\right)\end{array}$ & $\begin{array}{c}\text { 変 形 } \\
\text { 係 数 } \\
E_{0} \\
\left(\mathrm{kN} / \mathrm{m}^{2}\right)\end{array}$ & $\begin{array}{c}\text { ポアソン } \\
\text { 比 } \\
v\end{array}$ & $\begin{array}{c}\text { せん断 } \\
\text { 弾性係数 } \\
G_{0} \\
\left(\mathrm{kN} / \mathrm{m}^{2}\right)\end{array}$ & $\begin{array}{c}\text { せん断 } \\
\text { 強度 } \\
\mathrm{Su} \\
\left(\mathrm{kN} / \mathrm{m}^{2}\right)\end{array}$ & $\begin{array}{c}\text { せん断 } \\
\text { 弾性波 } \\
\text { 速度 } \\
V_{s} \\
(\mathrm{~m} / \mathrm{s})\end{array}$ \\
\hline $\mathrm{Bd}$ & 砂質土 & 6.8 & 3 & 19.0 & 74,000 & 0.3 & 28,000 & 33 & 118 \\
\hline As & 砂 & 5.0 & 1 & 17.0 & 31,000 & 0.3 & 12,000 & 11 & 76 \\
\hline Ac & 粘土質シルト & 5.0 & 2 & 16.5 & 53,000 & 0.3 & 20,000 & 24 & 100 \\
\hline $\mathrm{Ag}$ & 砂碟 & 2.5 & 36 & 20.0 & 536,000 & 0.3 & 206,000 & 242 & 317 \\
\hline Nsl & 頁岩 & 3.5 & 50 & 20.0 & 699,000 & 0.3 & 269,000 & 244 & 363 \\
\hline \multicolumn{4}{|c|}{ 複合地盤の改良体 } & 17.0 & 124,000 & 0.17 & 53,000 & 157 & 175 \\
\hline
\end{tabular}

と同等とした. また，橋台・杭と周辺地盤を取り囲むよ うに底面および側面粘性境界要素を配置した。これには， 8 節点平面要素の自由度を縮退した 6 節点接合(ジョイ

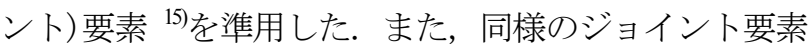
を用い構造物要素モデルと地盤の間の接触・剥離も考慮 した（図-4(c)）。図-4(d) は解析モデルの杭近傍を平面 的に表した模式図である. 断面内の杭と地盤の不連続性 をジョイント要素で再現するとともに，同一座標上に配 置した異なる節点を構成節点として杭と地盤の要素を重 ね合わせた，そうすることで，奥行き方向の杭と地盤の 不連続性を擬似的に再現した，なお，橋台躯体は杭要素 に支持されている.

\section{(2)材料構成則と材料特性値}

地震動による杭や地盤の地震時挙動を精度良く推定す るため, 杭と地盤の両者に非線形性を考慮した構成則 ${ }^{9)}$ を用いた. 杭体の RC 要素に岡村・前川ら ${ }^{19), 20) に よ る ~ R C ~}$ の履歴依存型非線形材料構成則を適用した. 本構成則に は非直交多方向固定ひび割れモデルや鉄筋の座屈モデル など, 鉄筋コンクリートの強非線形領域における適用性 も検証されている.これにより, 杭部材ではせん断変形が 卓越するケースも十分想定されるが, ひび割れ発生以降 のせん断変形に対しても評価することが可能となる.ま た, 周囲からの拘束圧に基づく $\mathrm{RC}$ の拘束効果も表すこ とができ, 本モデルのように $\mathrm{RC}$ 部材が地盤要素に取り 囲まれている場合には, 周囲からの圧力に基づく拘束効 果が考慮される. RC 要素に入力する材料特性值は, コン クリートの設計圧縮強度 $f^{{ }^{\prime}}{ }_{c}=24 \mathrm{~N} / \mathrm{mm}^{2}$, 引張強度 $f_{t}$ $=1.914 \mathrm{~N} / \mathrm{mm}^{2}$, 鉄筋の設計降伏強度 $f_{y}=345 \mathrm{~N} / \mathrm{mm}^{2}$ とした ${ }^{21)}$. フーチングや橋台部分は線形弾性体としてモデル化した。

2 次元動的非線形有限要素法に用いた地盤物性值の単 位体積重量 $\rho$, 変形係数 $E_{0}$, ポアソン比 $v$, せん断弾性波速 度 $V_{s}$ を表-1 に示す.

また, 粘性境界要素は地盤物性值から, 式(4)および式(5) で定めた粘性係数 $\mu よ り$ 設定した.
(鈆 直) $\mu_{N}=\rho \cdot V_{P}=\sqrt{\frac{2(1-v)}{1-2 v}} V_{S}$

（せん断） $\mu_{S}=\rho \cdot V_{S}$

橋台・杭一地盤間のジョイント要素は, 引張およびせ ん断岡性をゼロ（すなわち周面摩擦を無視したことと等 価）とし, 閉合方向に対しては高い圧縮岡性を与え地盤 要素と RC 要素が重ならないように考慮にした. なお, 杭 先端に位置するジョイント要素に限り杭が $N$ 值=50 の基 盤に根入れされているため, 要素の開閉方向に高い引張 剛性も与え橋台の水平応答に伴う杭の引抜けが生じない よう配慮した。

動的解析を行う際に考慮する減衰特性は, コンクリー 卜標準示方書 ${ }^{21)}$ に基づき材料構成則における履歴減衰 のみとした. モデル底面・側面に配置した粘性境界要素 の逸散減衰を除き, その他の粘性減衰は考慮しない. これ は, 杭一地盤系の減衰性状を定量的に評価して解析条件 に設定することが困難であることから, 安全側の応答值 を得るよう配慮したためである.

本検討は全応力で解析し, 地盤要素の偏差応力一偏差 ひずみ関係に Ohsaki モデル22)の履歴則を適用した. せん 断弾性係数 $G_{0}$ およびせん断強度 $S_{u}$ は, 地盤柱状と標準貫 入試験結果から以下の式(6), 式(7)を用いて設定した ${ }^{22)}$.

$$
\begin{aligned}
G_{0} & =11.76 N^{0.8} & & \\
S_{u} & =G_{0} / 1100 & & \text { (砂質土) } \\
& =G_{0} / 600 & & \text { (粘性士) }
\end{aligned}
$$

ここに, $N$ : 標準貫入試験から得られる $N$ 值である.なお, 体積変形成分については線形弾性とし繰返しせん断変形 に起因するダイレイタンシーは考慮されていない. また, 変動する拘束圧縮力の変動幅は小さいものとし, 拘束圧 変動に伴うせん断強度の変化は考慮しない. 


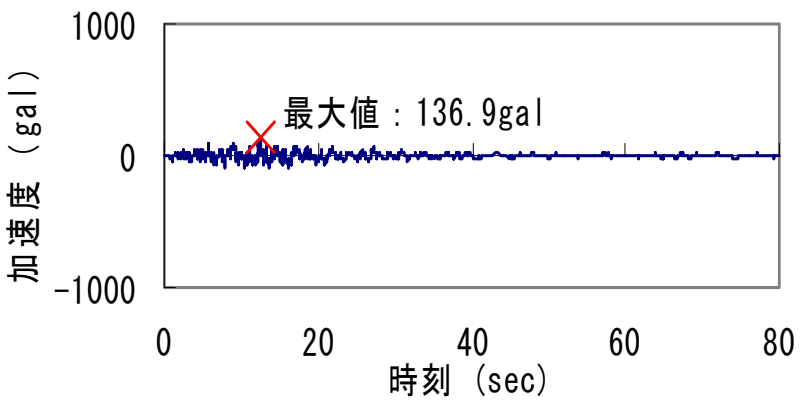

(a) レベル 1 地震動の加速度時刻歴

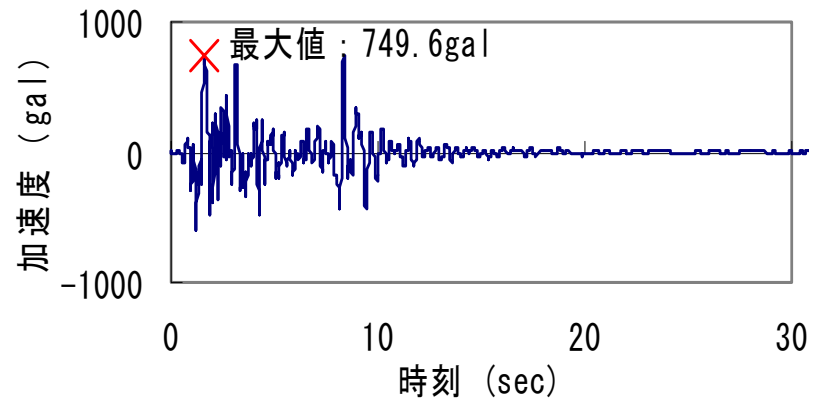

(b) レベル 2 地震動の加速度時刻歴

図-5 入力地震動の時刻歴加速度波形（×は加速度の最大值を示す）

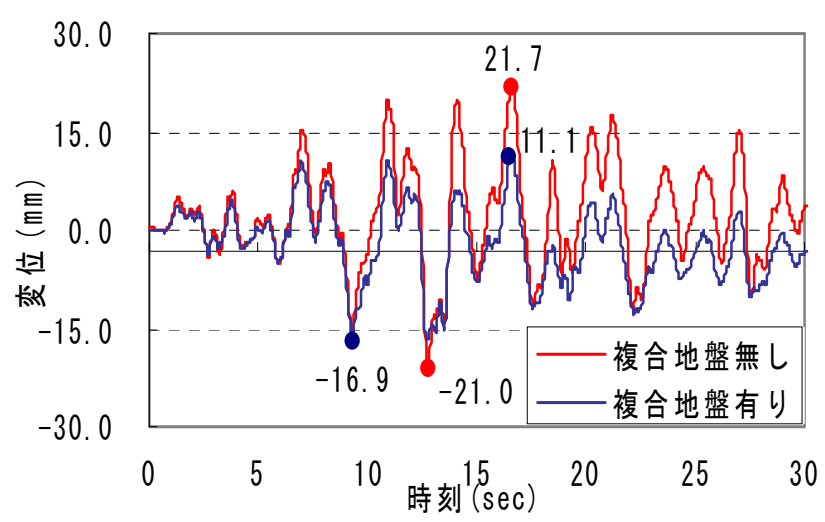

図-6 フーチング中央の杭水平変位の時刻歴応答 (レベル 1 地震動)

\section{（3）境界条件と荷重条件および入力地震波形}

境界条件はモデル最下端の節点を全て拘束とし, 粘性 境界要素外側の自由地盤要素の節点を水平ローラー（鉛 直方向自由度を拘束）とした.

本解析では, 各要素に相応の単位体積質量を与えるが モデル全体の鉛直方向の重力加速度を無視し, 橋台自重 および桁反力は集中荷重として別途取り扱う. 事前に橋 台のみの自重解析を行い, 得られた杭軸力の初期分担を 節点荷重に変換して杭頭部に作用させた. また, 桁反力は 支承位置節点に集中荷重として作用させ, 同じ質量を有 する薄い要素を支承位置に貼り付けた.

地震波はモデル最底面に基盤波形（ $2 E$ 波）を橋軸方 向に入力した.ここでは, 土木学会コンクリート標準示方 書而震性能照查編 ${ }^{21)}$ における地震動波形を適用した. 本 地震波は既往の観測記録の加速度応答スペクトルに基づ き, 距離减衰式を用いて断層直上のスペクトルに変換し, かつ断層の破壊過程を考慮して設定した位相特性の加速 度時刻歴波形である.したがって, 多様な地震特性を内在 する波形であることから, 解析効率も勘案しこの 1 波の みに限定して解析を行うこととした. ただし,地震動の強

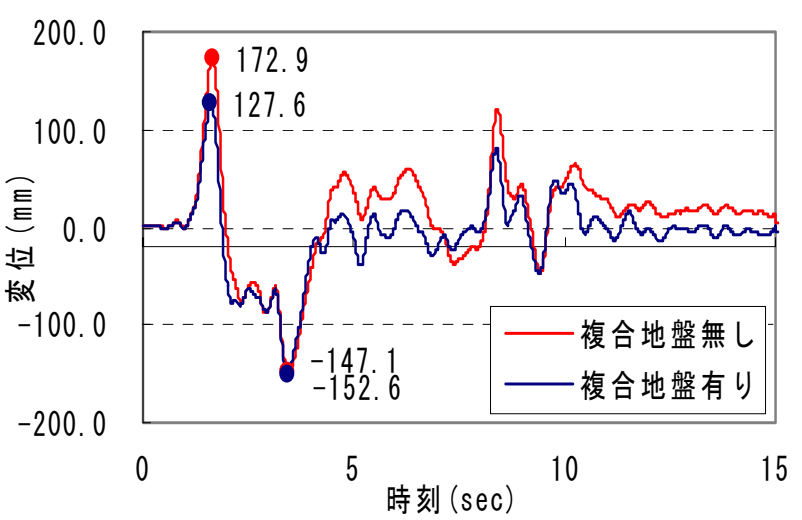

図-7 フーチング中央の杭水平変位の時刻歴応答 (レベル 2 地震動)

さによる影響も検討するため, レベル 1 地震動およびレ ベル 2 地震動波形を使用した. レベル 1 とレベル 2 地震 動の原波を図-5に示寸.動的解析に際し,波形の主要動部 分 (12 秒間) を取り出して, Newmark の $\beta$ 法 $(\beta=0.36)$ による直接積分を行った. 時間刻みは 0.01 秒である.

\section{5. 複合地盤の有無による杭の地震時挙動の検討}

複合地盤が杭の地震時挙動に及ぼす効果を確認するた め，まず，複合地盤有りと無しの場合について解析を実 施した. 解析モデルは前記した現場モデル（図-4）を対 象とした. 設計で設定した実際の状態を反映し, 複合地盤 有りの場合の改良範囲は, 深さを杭特性長 $1 / \beta=7.0 \mathrm{~m}$, 幅 を受働すべり面領域（作用勾配 $\left.\theta=\left(45^{\circ}+\phi / 2\right)\right)$ の $7.0 \mathrm{~m}$ とし, 改良強度は $q_{v p}=400 \mathrm{kN} / \mathrm{m}^{2}$ とした. また, レベル 1 地震動およびレベル2 地震動に対して解析した.

\section{(1) 杭水平変位}

図-6，図-7 は, 複合地盤無しと有りでレベル 1 地震動 およびレベル2 地震動を入力した際に, 解析で得られた 


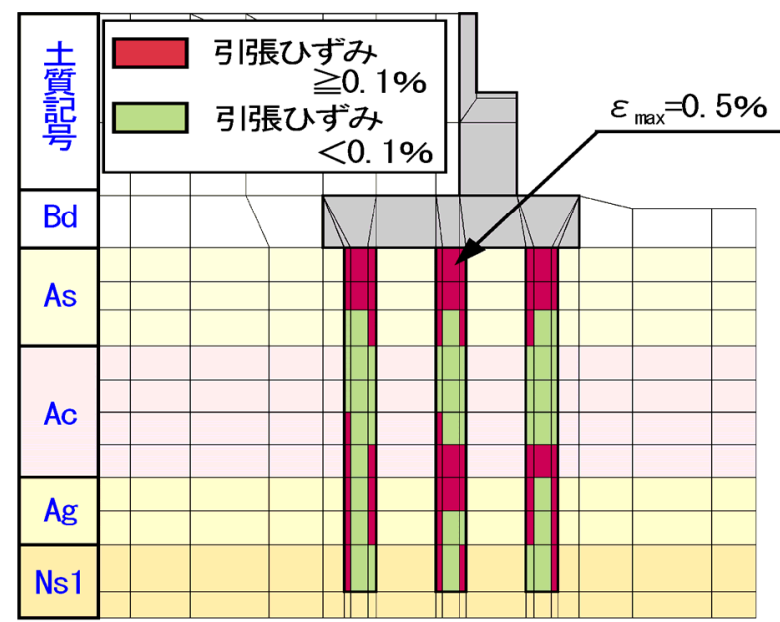

図-8 杭ひずみの発生状況（レベル 2 地震動） (複合地盤無し)

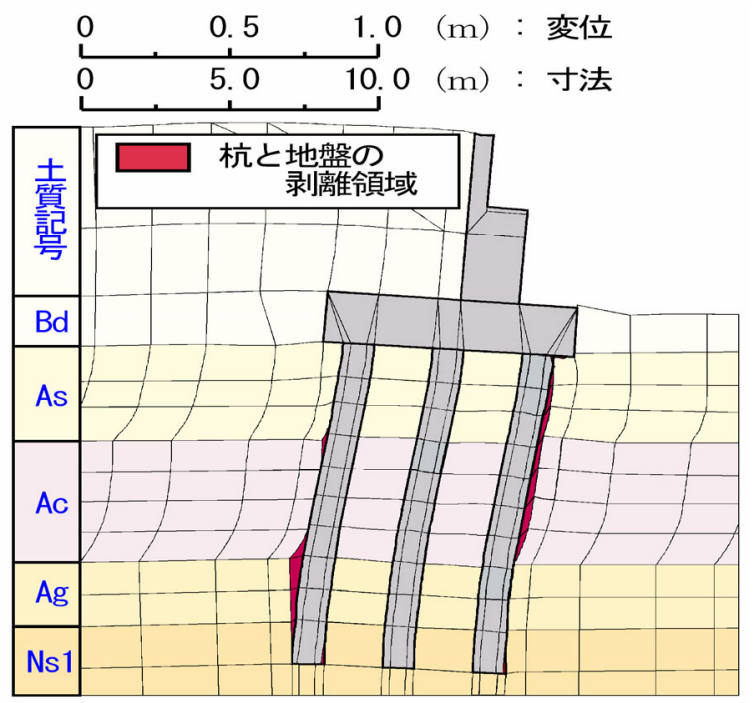

図-10 最大水平変位時の水平変位分布（レベル 2 地震動） (複合地盤無し)

中央杭の杭水平変位の時刻歴を示している．なお，本解 析は，複合地盤の存在が地震時に杭へ及ぼす影響を考察 することを目的としているため，橋台基礎ではなく杭そ のもののに着目寸る意味から，杭水平変位は杭下端に対 寸る杭頭の相対変位で整理した. 正が橋台前面側への変 位,負が橋台背面側への変位を表す。

背面側の応答変位波形は，レベル 1 地震動およびレベ ル 2 地震動とも複合地盤の有無でさほど変化は無いが, 前面側の応答変位波形は複合地盤有りの方が振幅が小さ くなっている. その結果, レベル 1 地震動では, 複合地盤 無しの前面側の最大水平変位 $21.7 \mathrm{~mm}$ が有りでは 5 割の $11.1 \mathrm{~mm}$ まで減少している. また, レベル 2 地震動では, 複 合地盤無しの前面側の最大水平変位 $172.9 \mathrm{~mm}$ が, 有りで はその 7割程度の $127.6 \mathrm{~mm}$ に減少している.つまり,複合

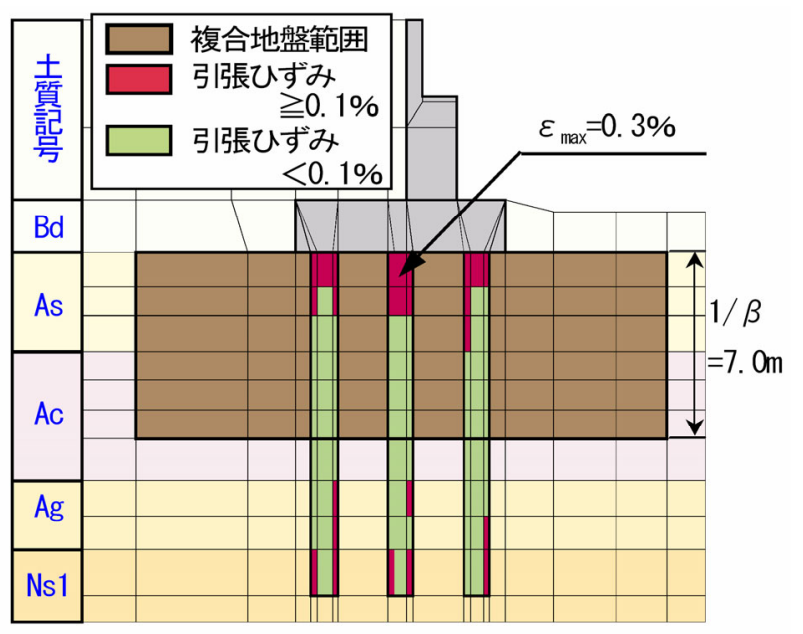

図-9 杭ひずみの発生状況（レベル 2地震動） （複合地盤有り）

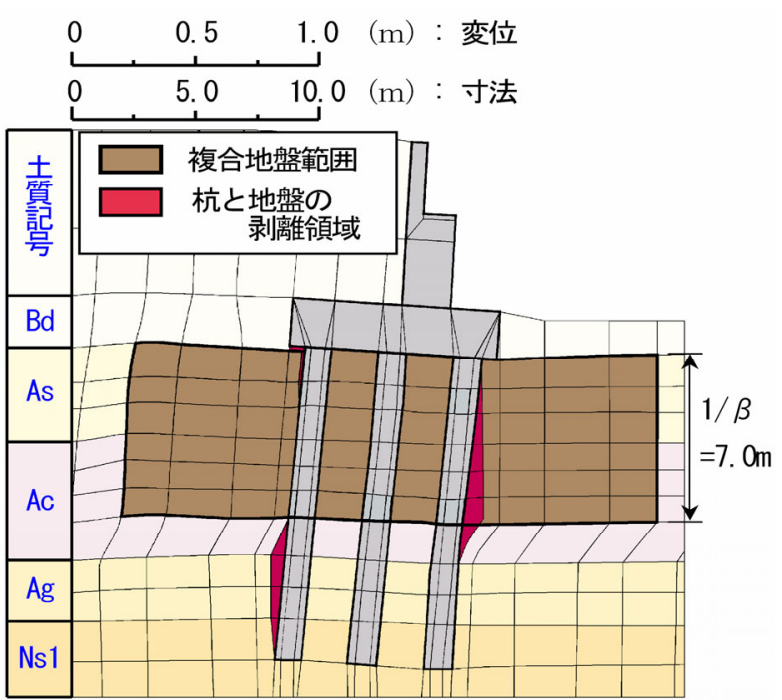

図-11 最大水平変位時の水平変位分布（レベル 2 地震動） (複合地盤有り)

地盤を施すことで地震時に杭水平変位が抑制される傾向 を示した。

\section{(2) 杭ひずみ}

レベル2地震動における複合地盤無しと有りの杭ひず みの発生状況を図-8, 図-9に示す. 杭体のひび割れ時の ひび割れ直交方向のコンクリートの平均引張ひずみに着 目し,ひずみ值0.1\%を限界值として区分した. なお, $0.1 \%$ はRC部材の通常使用状態の限界值として鉄筋応力度が $140 \mathrm{~N} / \mathrm{mm}^{2}$ 程度のひずみを設定したものである ${ }^{18)}$.

これによると, 複合地盤無しの場合は杭頭部と杭地中 部から杭先端までの広い範囲に限界值を上回るひずみ履 歴を受けているのに対し，複合地盤有りでは限界值の領 域が小さくなる，杭ひずみの最大值も複合地盤無しの場 
表-2 パラメトリックスタディの解析ケースと解析結果

\begin{tabular}{|c|c|c|c|c|c|c|c|c|c|c|c|c|c|}
\hline \multirow{4}{*}{$\begin{array}{l}\text { 検討 } \\
\text { ケース }\end{array}$} & \multirow{4}{*}{$\begin{array}{c}\text { 改良深さ } \\
\text { (m) }\end{array}$} & \multirow{4}{*}{$\begin{array}{l}\text { 改良幅 } \\
(\mathrm{m})\end{array}$} & \multirow{4}{*}{$\begin{array}{c}\text { 改良体 } \\
\text { 強 度 } \\
q_{u p} \\
\left(\mathrm{kN} / \mathrm{m}^{2}\right)\end{array}$} & \multicolumn{5}{|c|}{ レベル1地震動 } & \multicolumn{5}{|c|}{ レベル2地震動 } \\
\hline & & & & \multicolumn{2}{|c|}{ 相対変位(mm) } & \multicolumn{2}{|c|}{ 杭体ひずみ } & $\varepsilon$ & \multicolumn{2}{|c|}{ 相対変位(mm) } & \multicolumn{3}{|c|}{ 杭体ひずみ $\varepsilon$} \\
\hline & & & & \multirow{2}{*}{$\max$} & \multirow{2}{*}{$\min$} & \multicolumn{3}{|c|}{ 杭 頭 } & \multirow{2}{*}{$\max$} & \multirow{2}{*}{$\min$} & \multicolumn{3}{|c|}{ 杭 頭 } \\
\hline & & & & & & 引張 & 圧縮 & せん断 & & & 引張 & 厓縮 & せん断 \\
\hline $0-0$ & & 複合地盤無し & & 21.7 & -21.0 & $4.17 \mathrm{E}-04$ & $-3.74 \mathrm{E}-04$ & $5.53 \mathrm{E}-05$ & 172.9 & -147.1 & $4.80 \mathrm{E}-03$ & $-2.15 \mathrm{E}-03$ & 6.39E-04 \\
\hline $1-1$ & \multirow{9}{*}{$\begin{array}{l}1 / \beta \\
=7.0\end{array}$} & \multirow{3}{*}{$\begin{array}{c}\text { 受働域 } \times 1.0 \\
\quad=7.0\end{array}$} & 400 & 11.1 & -16.9 & $3.59 \mathrm{E}-04$ & $-2.77 \mathrm{E}-04$ & 5.81E-05 & 127.6 & -152.6 & $2.53 \mathrm{E}-03$ & $-8.94 \mathrm{E}-04$ & $4.13 \mathrm{E}-04$ \\
\hline $1-2$ & & & 200 & 12.7 & -17.1 & $3.17 \mathrm{E}-04$ & $-2.55 \mathrm{E}-04$ & $4.69 \mathrm{E}-05$ & 136.8 & -143.2 & $2.15 \mathrm{E}-03$ & $-1.13 \mathrm{E}-03$ & $3.22 \mathrm{E}-04$ \\
\hline $1-3$ & & & 800 & 9.8 & -16.3 & $3.42 \mathrm{E}-04$ & $-2.73 \mathrm{E}-04$ & $4.82 \mathrm{E}-05$ & 123.2 & -155.2 & $2.72 \mathrm{E}-03$ & $-1.01 \mathrm{E}-03$ & $5.24 \mathrm{E}-04$ \\
\hline $1-4$ & & \multirow{3}{*}{$\begin{array}{c}\text { 受働域 } \times 0.5 \\
=3.5\end{array}$} & 400 & 14.0 & -17.9 & $3.59 \mathrm{E}-04$ & $-2.69 \mathrm{E}-04$ & $5.61 \mathrm{E}-05$ & 138.9 & -139.3 & $1.98 \mathrm{E}-03$ & $-9.93 \mathrm{E}-04$ & -04 \\
\hline $1-5$ & & & 200 & 16.1 & -18.8 & $3.48 \mathrm{E}-04$ & $-2.64 \mathrm{E}-04$ & $4.20 \mathrm{E}-05$ & 148.3 & -153.6 & $2.11 \mathrm{E}-03$ & $-1.23 \mathrm{E}-03$ & $3.59 \mathrm{E}-04$ \\
\hline $1-6$ & & & 800 & 12.8 & -17.5 & $3.63 \mathrm{E}-04$ & $-2.73 \mathrm{E}-04$ & $6.78 \mathrm{E}$ & 132.2 & -148.2 & $2.72 \mathrm{E}-03$ & $-9.98 \mathrm{E}-04$ & 5.07E-04 \\
\hline $1-7$ & & \multirow{3}{*}{$\begin{array}{c}\text { 受働域 } \times 1.5 \\
=10.5\end{array}$} & 400 & 10.4 & -16.2 & $3.37 \mathrm{E}-04$ & $-2.68 \mathrm{E}-04$ & $5.45 \mathrm{E}-05$ & 124.0 & -159.4 & $2.38 \mathrm{E}-03$ & $-8.80 \mathrm{E}-04$ & 3.79E-04 \\
\hline $1-8$ & & & 200 & 12.6 & -16.0 & $3.22 \mathrm{E}-04$ & $-2.66 \mathrm{E}-04$ & $4.90 \mathrm{E}-05$ & 133.0 & -149.5 & $2.39 \mathrm{E}-03$ & $-9.28 \mathrm{E}-04$ & $3.21 \mathrm{E}-04$ \\
\hline $1-9$ & & & 800 & 9.2 & -16.2 & $3.36 \mathrm{E}-04$ & $-2.80 \mathrm{E}-04$ & $6.14 \mathrm{E}-05$ & 119.2 & -162.7 & $2.51 \mathrm{E}-03$ & $-1.02 \mathrm{E}-03$ & $5.03 \mathrm{E}-04$ \\
\hline $2-1$ & \multirow{9}{*}{$\begin{array}{l}0.5 / \beta \\
=3.5\end{array}$} & \multirow{3}{*}{$\begin{array}{c}\text { 受働域 } \times 1.0 \\
\quad=7.0\end{array}$} & 400 & 12.7 & -19.9 & $3.98 \mathrm{E}-04$ & $-2.86 \mathrm{E}-04$ & $6.82 \mathrm{E}-05$ & 149.8 & -159.0 & $2.12 \mathrm{E}-03$ & $-1.01 \mathrm{E}-03$ & $4.51 \mathrm{E}-04$ \\
\hline $2-2$ & & & 200 & 13.9 & -19.0 & $3.52 \mathrm{E}-04$ & $-2.60 \mathrm{E}-04$ & $5.43 \mathrm{E}-05$ & 152.6 & -144.4 & $2.76 \mathrm{E}-03$ & $-1.09 \mathrm{E}-03$ & $2.89 \mathrm{E}-04$ \\
\hline $2-3$ & & & 800 & 12.2 & -20.8 & $4.27 \mathrm{E}-04$ & $-3.00 \mathrm{E}-04$ & $8.34 \mathrm{E}-05$ & 147.9 & -167.6 & $2.76 \mathrm{E}-03$ & $-7.40 \mathrm{E}-03$ & $5.35 \mathrm{E}-04$ \\
\hline $2-4$ & & \multirow{3}{*}{$\begin{array}{c}\text { 受働域 } \times 0.5 \\
\quad=3.5\end{array}$} & 400 & 14.9 & -19.6 & $4.13 \mathrm{E}-04$ & $-3.09 \mathrm{E}-04$ & $6.23 \mathrm{E}-05$ & 153.2 & -145.8 & $2.23 \mathrm{E}-03$ & $-9.68 \mathrm{E}-04$ & $3.89 \mathrm{E}-04$ \\
\hline $2-5$ & & & 200 & 16.3 & -19.1 & $3.78 \mathrm{E}-04$ & $-2.68 \mathrm{E}-04$ & $5.53 \mathrm{E}-05$ & 156.7 & -150.8 & $2.98 \mathrm{E}-03$ & $-1.13 \mathrm{E}-03$ & $3.78 \mathrm{E}-04$ \\
\hline $2-6$ & & & 800 & 14.0 & -19.7 & $4.13 \mathrm{E}-04$ & $-2.88 \mathrm{E}-04$ & \begin{tabular}{|l|}
$8.15 \mathrm{E}-05$ \\
\end{tabular} & 150.7 & -154.3 & $2.03 \mathrm{E}-03$ & $-1.36 \mathrm{E}-03$ & $4.67 \mathrm{E}-04$ \\
\hline $2-7$ & & \multirow{3}{*}{$\begin{array}{c}\text { 受働域 } \times 1.5 \\
=10.5\end{array}$} & 400 & 13.1 & -19.4 & $3.86 \mathrm{E}-04$ & $-2.81 \mathrm{E}-04$ & \begin{tabular}{|l|}
$7.06 \mathrm{E}-05$ \\
\end{tabular} & 149.6 & -166.2 & $2.14 \mathrm{E}-03$ & $-1.01 \mathrm{E}-03$ & $4.08 \mathrm{E}-04$ \\
\hline $2-8$ & & & 200 & 14.2 & -18.6 & $3.29 \mathrm{E}-04$ & $-2.56 \mathrm{E}-04$ & \begin{tabular}{|l}
$5.19 \mathrm{E}-05$ \\
\end{tabular} & 151.6 & -152.6 & $2.83 \mathrm{E}-03$ & $-1.24 \mathrm{E}-03$ & $2.90 \mathrm{E}-04$ \\
\hline $2-9$ & & & 800 & 12.5 & -21.2 & $4.57 \mathrm{E}-04$ & $-3.10 \mathrm{E}-04$ & $8.67 \mathrm{E}-05$ & 148.2 & -176.5 & $2.35 \mathrm{E}-03$ & $-9.88 \mathrm{E}-04$ & $5.02 \mathrm{E}-04$ \\
\hline $3-1$ & \multirow{9}{*}{$\begin{array}{l}1.5 / \beta \\
=10.5\end{array}$} & \multirow{3}{*}{$\begin{array}{c}\text { 受働域 } \times 1.0 \\
=7.0\end{array}$} & 400 & 9.8 & -14.6 & $2.85 \mathrm{E}-04$ & $-2.55 \mathrm{E}-04$ & $4.48 \mathrm{E}-05$ & 85.7 & -142.8 & $2.99 \mathrm{E}-03$ & $-1.14 \mathrm{E}-03$ & $4.36 \mathrm{E}-04$ \\
\hline $3-2$ & & & 200 & 12.8 & -19.0 & $3.75 \mathrm{E}-04$ & $-2.82 \mathrm{E}-04$ & $5.06 \mathrm{E}-05$ & 127.1 & -142.8 & $2.16 \mathrm{E}-03$ & $-9.96 \mathrm{E}-04$ & $3.52 \mathrm{E}-04$ \\
\hline $3-3$ & & & 800 & 7.9 & -11.5 & $2.17 \mathrm{E}-04$ & $-2.30 \mathrm{E}-04$ & $3.71 \mathrm{E}-05$ & 57.7 & -107.7 & $2.87 \mathrm{E}-03$ & $-1.12 \mathrm{E}-03$ & $3.66 \mathrm{E}-04$ \\
\hline & & & 400 & 14.0 & -16.2 & $3.26 \mathrm{E}-04$ & $-2.60 \mathrm{E}-04$ & $5.03 \mathrm{E}-05$ & 121.3 & -161.4 & $2.64 \mathrm{E}-03$ & $-1.19 \mathrm{E}-03$ & $4.22 \mathrm{E}-04$ \\
\hline & & & 200 & 16.3 & -20.4 & $4.16 \mathrm{E}-04$ & $-2.78 \mathrm{E}-04$ & $5.13 \mathrm{E}-05$ & 150.8 & -175.5 & $2.32 \mathrm{E}-03$ & $-1.05 \mathrm{E}-03$ & $3.03 \mathrm{E}-04$ \\
\hline $3-6$ & & & 800 & 11.3 & -14.4 & $2.76 \mathrm{E}-04$ & $-2.48 \mathrm{E}-04$ & $5.15 \mathrm{E}-05$ & 100.4 & -143.6 & $3.16 \mathrm{E}-03$ & $-1.29 \mathrm{E}-03$ & $4.15 \mathrm{E}-04$ \\
\hline $3-7$ & & & 400 & 8.6 & -12.5 & $2.79 \mathrm{E}-04$ & $-2.23 \mathrm{E}-04$ & $3.75 \mathrm{E}-05$ & 66.9 & -120.7 & $2.37 \mathrm{E}-03$ & $-9.02 \mathrm{E}-04$ & $2.56 \mathrm{E}-04$ \\
\hline & & & 200 & 12.1 & -17.8 & $3.41 \mathrm{E}-04$ & $-2.69 \mathrm{E}-04$ & $4.84 \mathrm{E}-05$ & 111.5 & -140.3 & $2.18 \mathrm{E}-03$ & $-9.61 \mathrm{E}-04$ & $3.19 \mathrm{E}-04$ \\
\hline & & & 800 & 4.9 & -7.9 & $1.79 \mathrm{E}-04$ & $-2.17 \mathrm{E}-04$ & $4.77 \mathrm{E}-05$ & 40.4 & -87.0 & $2.13 \mathrm{E}-03$ & $-8.93 \mathrm{E}-04$ & $2.30 \mathrm{E}-04$ \\
\hline
\end{tabular}

合で最大 $\varepsilon_{\text {max }}=0.5 \%$ であるのに対し複合地盤有りの場合 は同位置で最大 $\varepsilon_{\text {max }}=0.3 \%$ である.これは, 複合地盤の存 在により地震時の杭水平変位が抑制され, 杭体のひび割 れ発生領域が縮小したためと考えられる.

\section{(3)地盤の変形}

レベル 2 地震動で解析した複合地盤の有無による地盤 変形の状況を図-10, 図-11 に示寸. 図中の赤く着色し た部分は杭体と地盤が剥離した領域を示している.

複合地盤無しの場合は，軟弱層である As 層(ゆるい砂 層)・Ac 層(粘土質シルト層)内で杭間を含む地盤全体が 水平方向に変形しており, これに同調して杭も変位して いる. 剥離領域は, 前面杭の軟弱層の範囲全体に及んで いる. これに対し複合地盤有りでは，軟弱層内の杭間を 含む地盤全体のせん断変形が抑制されており，特に杭前 面側地盤では変形が小さい．ただし，杭前面と背面の軟 弱層下部の未改良地盤に，比較的大きなせん断変形が発 生している.これは, 複合地盤により地震時に変形が抑 制されるが，複合地盤下面に応力が集中寸るためと考え られる. 複合地盤と未改良地盤の岡性差が大きい場合, このような影響が発生することに留意する必要がある.
なお，複合地盤有りでは剥離領域は，複合地盤無しと ほぼ同様の範囲であるが，前面側地盤の水平変形が小さ いため杭と地盤の剥離幅が大きくなっている.なお,杭と 地盤の剥離とは, 解析上で接合が切り離されたことを意 味する.

以上により, 複合地盤を杭周辺に施すことで, 複合地盤 無しの場合に対し, 地震時に杭水平変位, 杭ひずみ, 地盤 変形が抑制され而震性が向上する傾向が確認された. そ の際, レベル 1 地震動では杭の非線形化が生じないのに 対し, レベル 2 地震動では全体の変形が顕著である.

\section{6. 複合地盤の改良深さ · 改良幅・改良強度が杭の 地震時挙動に与える影響}

\section{(1)パラメトリックスタディ}

前節では, 複合地盤の改良範囲を杭特性長 $1 / \beta$ を基 準とした場合で，地盤改良無しの場合に比べて杭水平変 位，杭ひずみおよび地盤変形が抑制される傾向を示した. しかし，1/ $\beta$ を指標とした範囲が合理的な改良範囲を与 えているかや改良強度の変化の影響は不明である.

そこで, 複合地盤のパラメータが杭の地震時挙動に及 


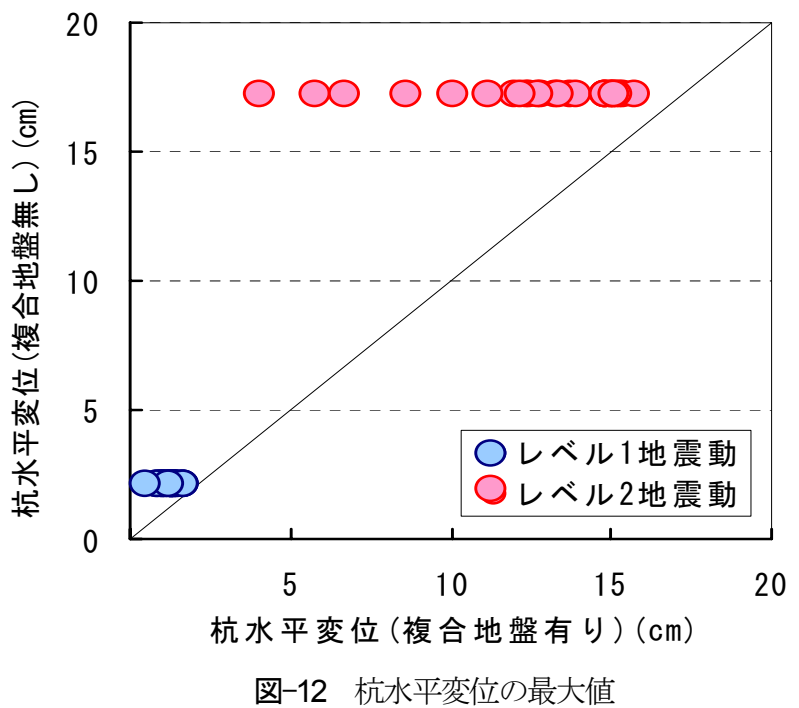

ぼす影響を詳細に検討寸るため, 複合地盤の改良深さ, 改良幅およひ改良強度を種々に変化させたパラメトリ ックスタディを実施した，すなわち，複合地盤の改良 強度 $q_{u p}=400 \mathrm{kN} / \mathrm{m}^{2}$ を基準值に $200 \mathrm{kN} / \mathrm{m}^{2}$ と $800 \mathrm{kN} / \mathrm{m}^{2}$ に変 化させ, 改良範囲については杭特性長 $1 / \beta$ を基本とし 改良深さを $0.5 / \beta$ と $1.5 / \beta$, 改良幅の受働土圧領域を 0.5 倍と 1.5 倍としたケースで解析した. レベル 1 地震動 とレベル 2 地震動を対象に, それぞれ 28 ケースの全 56 ケースの解析を行った. 解析ケースを表-2に示した. 解 析に用いた複合地盤の改良体の変形係数 $E_{0}$, せん断弾 性係数 $G_{0}$ およびせん断弾性波速度 $V_{s}$ は表-1 に示した.

本検討では，地震時における杭水平変位，杭ひずみ， 地盤変形に着目し，各パラメータの変化がそれぞれの 動的応答值に与える影響を考察した。

\section{(2) 杭水平変位}

解析の結果得られた，レベル1地震動とレベル2地震動 における杭の最大水平変位を表-2に示した.

複合地盤無しと有りの解析結果を対比し，図-12に杭 水平変位の違いを整理した. これによると, レベル1地 震動およびレベル2地震動において, 複合地盤有りでは複 合地盤無しに比べて杭水平変位は減少している. 特に, レベル2地震動に対してはレベル1地震動に比べて複合地 盤のパラメータの変化で杭水平変位の差の幅が大きい. 寸なわち, 改良範囲や改良強度の変化で杭水平変位に比 較的大きな差が生じている.

以上の結果, 複合地盤のパラメータの変化が杭の地震 時挙動に大きな影響を及ぼすと判断した. そこで, 複合 地盤の改良深さ, 改良幅, 改良強度の3つのパラメータが

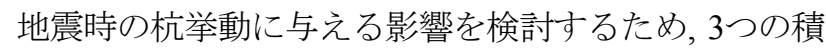

（深さ×幅 $\times$ 強度）をそれぞれの基準值の積（基準深さ

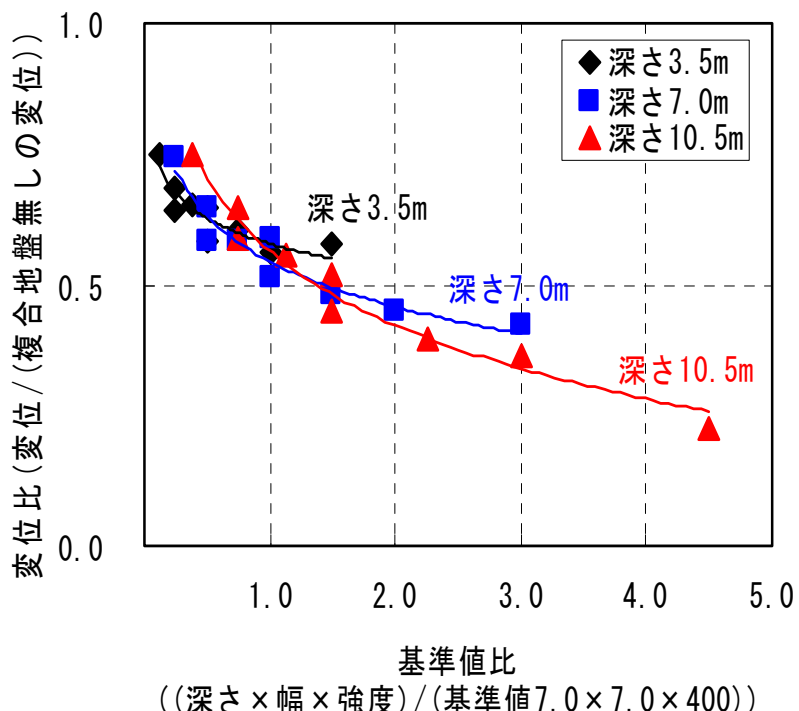

図-13 基準值比と変位比の関係（レベル 1 地震動）

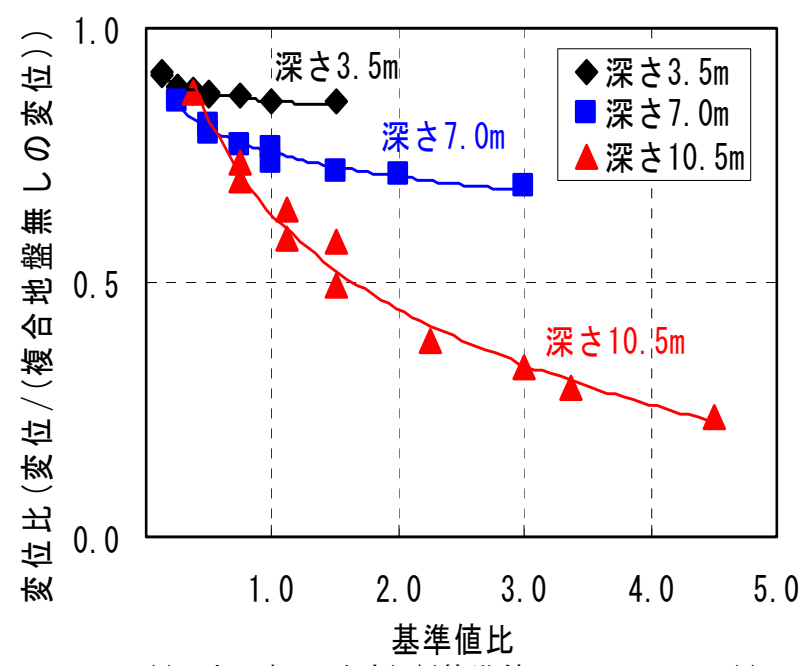

((深さ $\times$ 幅 $\times$ 強度 $) /($ 基準値 $7.0 \times 7.0 \times 400))$

図-14 基準值比と変位比の関係（レベル 2 地震動）

$7.0 \mathrm{~m} \times$ 基準幅 $7.0 \mathrm{~m} \times$ 基準強度 $400 \mathrm{kN} / \mathrm{m}^{2}$ ) で除した值を基 準值比として以下に検討した. この際, 積は水平抵抗力を 表し,基準值比はパラメータの増加指標である.

レベル1地震動とレベル2地震動で解析した基準值比を 改良深さの関係で整理し，それぞれ図-13および図-14に 示す，縦軸は, 複合地盤無しの杭水平変位に対する各検 討ケースの変位比とした. この結果, 図示したように改 良深さ3.5m, 7.0mおよび10.5mで一定の相関が認められた. 図に示した近似曲線によれば，レベル1地震動では基準 值比が大きくなるに従い変位比が小さくなる傾向にある. 改良深さにより変位比一の影響は異なるものの, 同一の 基準值比では改良深さによらず概ね同一の変位比となっ ている. それに対しレベル2地震動では改良深さとの相 関性が強く, 同一の基準值比でも改良深さによって変位 


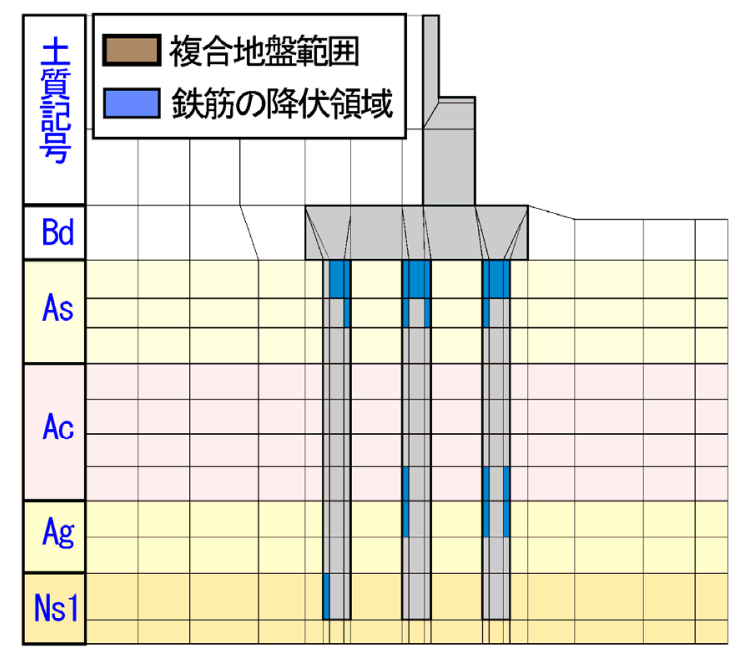

(a) 複合地盤無し

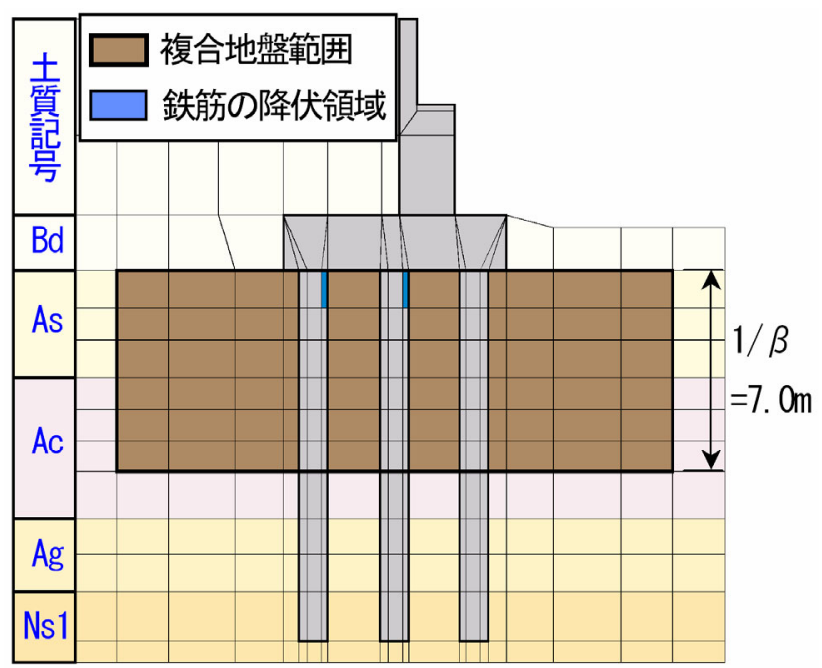

(c) ケース 1-1 ; 改良深さ $7.0 \mathrm{~m}$, 改良幅 $7.0 \mathrm{~m}$, 改良強度 $400 \mathrm{kN} / \mathrm{m}^{2}$

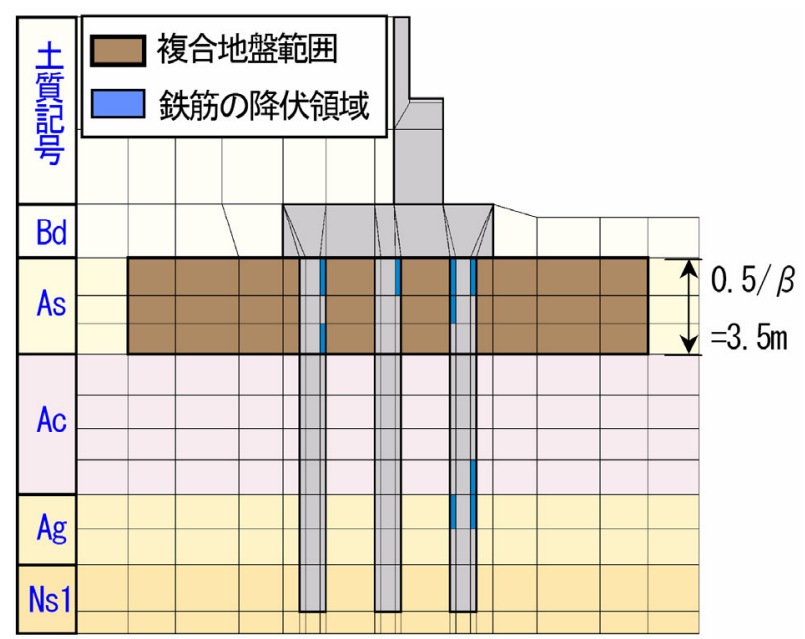

(b) ケース 2-1 ; 改良深さ $3.5 \mathrm{~m}$, 改良幅 $7.0 \mathrm{~m}$, 改良強度 $400 \mathrm{kN} / \mathrm{m}^{2}$

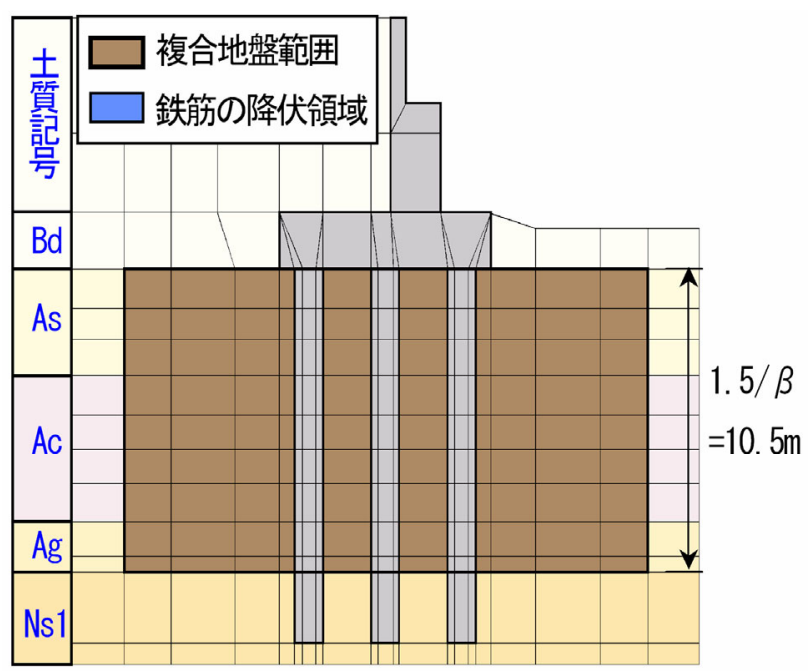

(d) ケース 3-1 ; 改良深さ $10.5 \mathrm{~m}$, 改良幅 7.0m, 改良強度 $400 \mathrm{kN} / \mathrm{m}^{2}$

図-15 最大杭ひずみの状況（レベル 2 地震動）

比が大きく異なる傾向を示している. つまり, 改良深さ

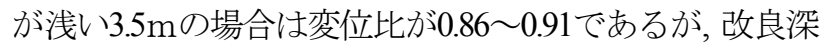
さが深い $10.5 \mathrm{~m}$ では変位比が $0.23 \sim 0.87$ と基準值比の影響 が顕著となる.これより，レベル1地震動のように地震 動の規模が小さい場合は複合地盤は杭の反力体としての 効果が発揮されるが，レベル2地震動のような大規模地 震動では, 複合地盤の深さが浅い場合, 反力体としての 効果が低減すると考えられる．また，改良深さが深くな るに従い変位比が低下するのは, 複合地盤による反力体 領域が杭に対して大きくなるためと考えられる. なお， 改良幅と改良強度で同様な整理をした場合, 表-2からも 分かるように，それぞれの増加により杭水平変位が微减 するが明瞭な傾向は認められていない.

杭水平変位最大時の杭体のひずみ分布を, 全56ケース
の解析の中で, レベル2地震動に着目し, 標準的な複合地 盤のパラメータを用いた場合（検討ケース1-1）と改良 深さを変化させた場合（検討ケース2-1, 3-1）の最大杭ひ ずみの状況を図-15に示す.ひずみの区分は, 杭体の軸方 向鉄筋の降伏ひずみを閾值とした. 図中の青色は杭体コ ンクリートの引張ひずみが降伏ひずみを上回った部分で ある.複合地盤無しではレベル2地震動に対し杭ひずみは 降伏に至っている.しかし, 改良深さが深くなるほど降伏 領域が減少し, 改良深さが $10.5 \mathrm{~m}$ では杭体は降伏していな い. これらの水平変位と杭ひずみの発現は, レベル1地 震動では杭はRC部材として弾性範囲にあり複合地盤の 剛性の影響を強く受けるのに対し，レベル2地震動では 杭体に引張降伏の応答が生じ塑性変形の影響を受けるた めと考えられる. 


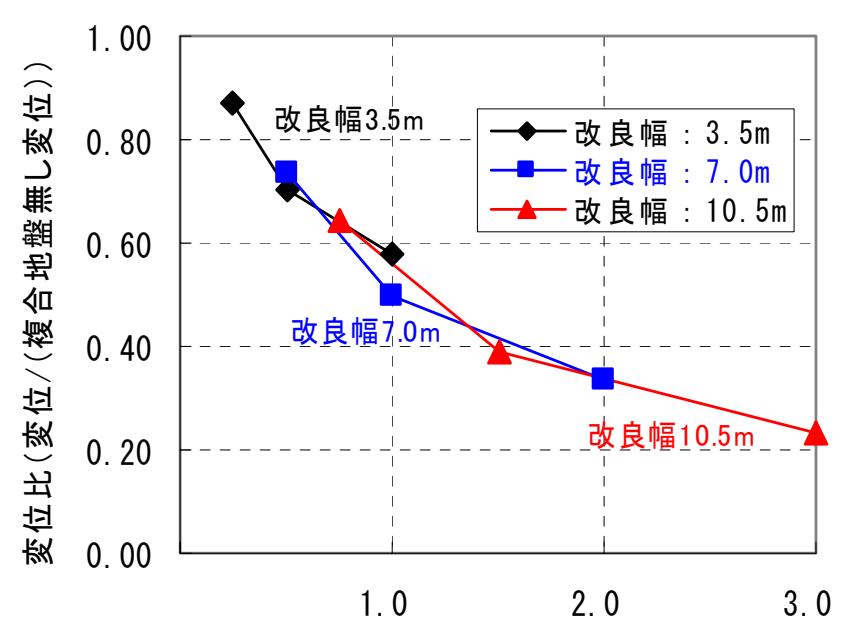

基準値比 $(($ 幅 $\times$ 強度 $) /($ 基準値 $7.0 \times 400))$

図-16 改良深さ $10.5 \mathrm{~m}$ の基準值比と変位比の関係 (改良幅に着目)（レベル2地震動）

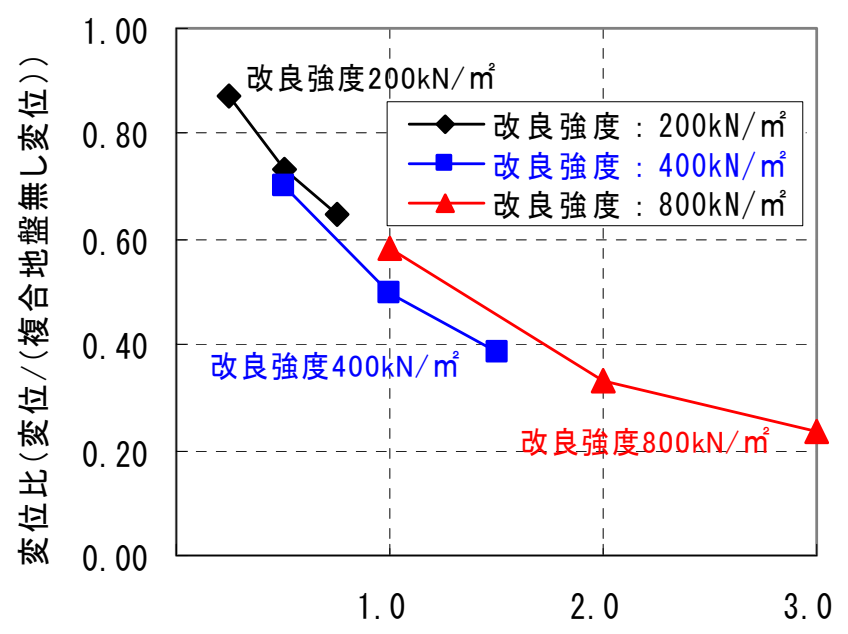

基準値比 $(($ 幅 $\times$ 強度 $) /($ 基準値 $7.0 \times 400))$

図-17 改良深さ $10.5 \mathrm{~m}$ の基準值比と変位比の関係 (改良強度に着目)（レベル2地震動）

次に，複合地盤の改良幅と改良強度が杭水平変位に与 える影響を検討するため, 基準值比の違いによる変化が 最も大きい改良深さ $10.5 \mathrm{~m}$ ケースのレベル2地震動にお ける改良幅と改良強度を変位比の関係でそれぞれ図-16, 図-17に整理した。横軸は, 改良幅と改良強度の積をそ れぞれの基準值(基準幅 $7.0 \mathrm{~m} \times$ 基準強度 $400 \mathrm{kN} / \mathrm{m}^{2}$ )の積で除 した值の基準值比とし, 縦軸は複合地盤無しの杭水平変 位に対する変位比とした.これらの図によれば, 基準值比 が大きくなるに従い変位比は減少し，その相関関係は改 良幅と改良強度に関係なく，同一曲線によるフィッティ ングが可能であることを示している. つまり，同じ基準 值比の組み合わせでは, 改良幅と改良強度の変化に関わ らず，同じ変位比の変化となっている.
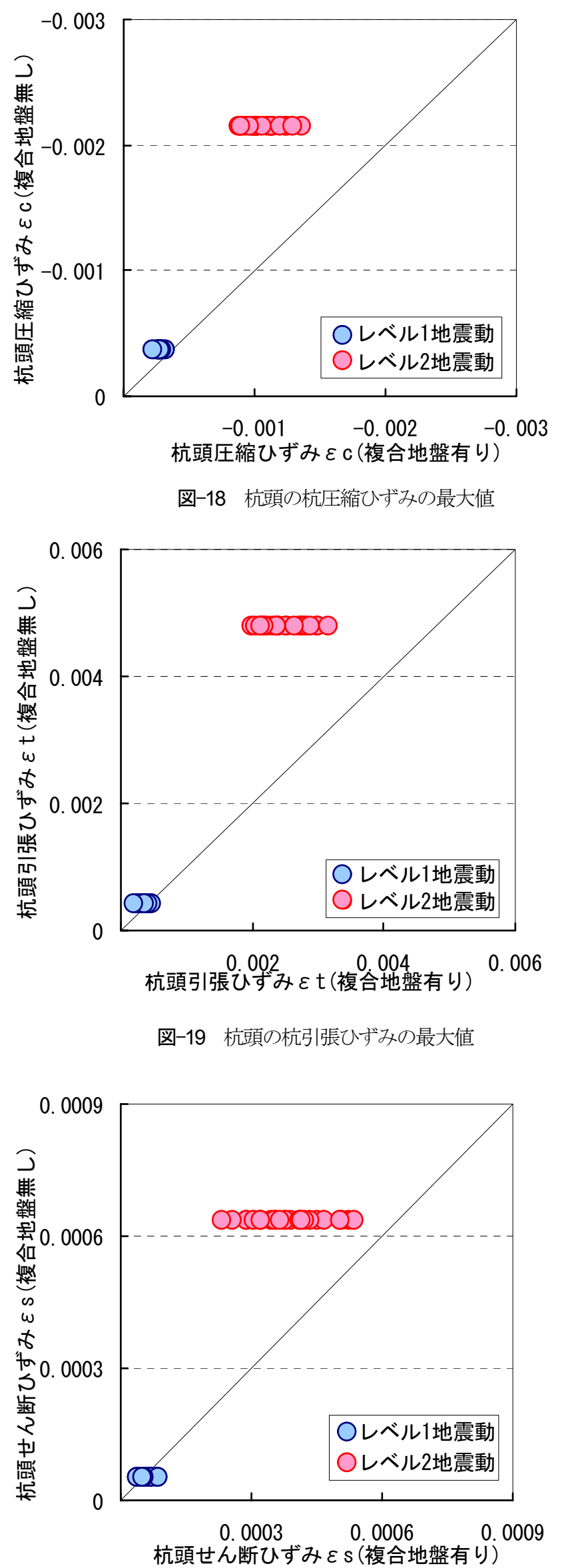

図-20 杭頭の杭せん断ひずみの最大值 


\section{(3)杭の圧縮ひずみ・引張ひずみ・せん断ひずみ}

解析で得られたレベル 1 地震動とレベル 2 地震動にお ける杭頭部および複合地盤境界面の杭圧縮ひずみ，杭引 張ひずみおよび杭せん断ひずみの最大值を表-2 に整理 し示した.

\section{a) 杭頭のひずみの変化}

杭頭部の杭圧縮ひずみ, 杭引張ひずみおよび杭せん断 ひずみの違いを複合地盤無しと有りで地震動別に対比し， それぞれ図-18, 図-19および図-20に示した。

杭圧縮ひずみ, 杭引張ひずみの最大值に着目すると, レベル 1 地震動に対しては複合地盤を施しても，ひずみ の減少は微小である。これに対し，レベル 2 地震動では いずれのケースにおいても，ひずみは比較的大きく減少 している. また，図-19 に示した杭せん断ひずみは，レ ベル 1 地震動では減少は認められないが, レベル 2 地震 動に対しては減少する傾向を示した.

次に，図-21 にレベル 1 地震動における基準值比と杭 頭部の杭引張ひずみの関係を整理した. 縦軸は, 杭の最大 ひずみを複合地盤無しの場合の值で除しひずみ比とした。 図によれば，基準值比が大きくなるに従いひずみ比が減 少する傾向にある. 図-22 にレベル 2 地震動における基 準值比と杭引張ひずみの関係を整理した．レベル 2 地震 動に対して，レベル 1 地震動と同様に基準值比が大きく なるに従いひずみ比が減少する傾向にある.この傾向に 差は認められない。

また，改良深さに着目すると深さ毎にひずみ比に差異 が生じており，レベル 1 地震動およびレベル 2 地震動と もに, 改良幅や改良強度によりひずみ比が影響を受ける と考えられる。

同様に図-23 および図-24 に，基準值比と杭せん断ひ ずみの関係をレベル 1 地震動とレベル 2 地震動に関して 整理した．縦軸は，それぞれの杭の最大ひずみを複合地 盤無しの場合の值で除しひずみ比とした. これによると， 図-23に示したレベル 1 地震動では, 改良深さと一定の 相関が認められる．また，改良深さが $3.5 \mathrm{~m}$ や $7.0 \mathrm{~m}$ では $10.5 \mathrm{~m}$ の場合とは異なり,ひずみ比が複合地盤無しに比べ て増加寸る場合がある.これに対し，図-24 に示寸レベ ル 2 地震動では, 相関性はないものの総じて複合地盤無 しの場合に比べて杭ひずみは減少する結果となった。ま た，改良深さとひずみ比の関係では，改良深さが大きく なると杭せん断ひずみは概ね減少し, それは改良深さ 3.5 $\mathrm{m}$ と改良深さ $7.0 \mathrm{~m}$ の場合より, 改良深さ $10.5 \mathrm{~m}$ でやや大 きい.

これらの傾向は，レベル 1 地震動では杭体は弾性範囲 にあるため杭せん断ひずみと比例的な関係となるが, レベル 2 地震動に対しては複合地盤の抑制効果が発揮さ れ，杭に作用寸るせん断力が低下寸るためと考えられる.

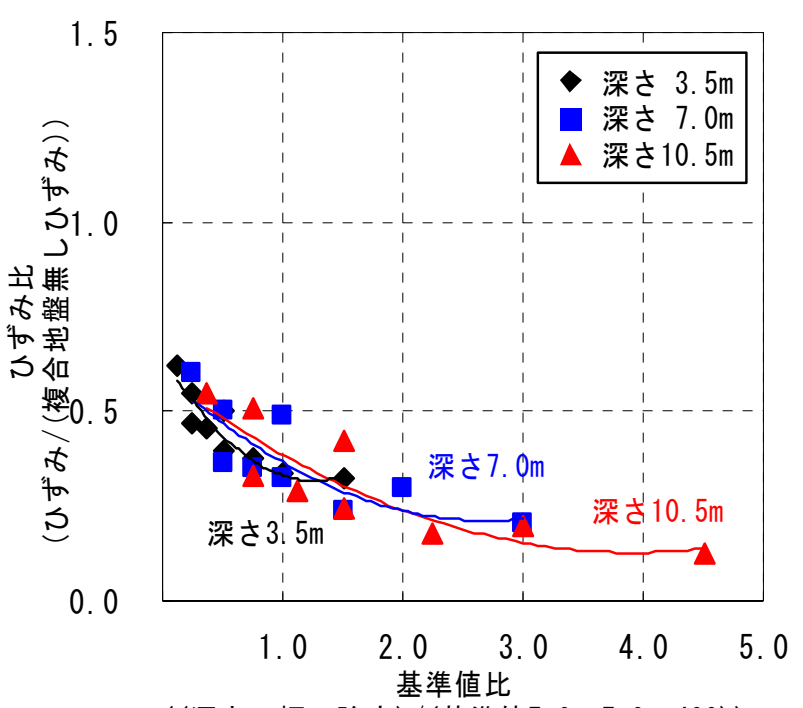

（(深さ $\times$ 幅 $\times$ 強度 $) /($ 基準值 $7.0 \times 7.0 \times 400)$ )

図-21 杭頭の杭引張ひずみ（レベル 1 地震動）

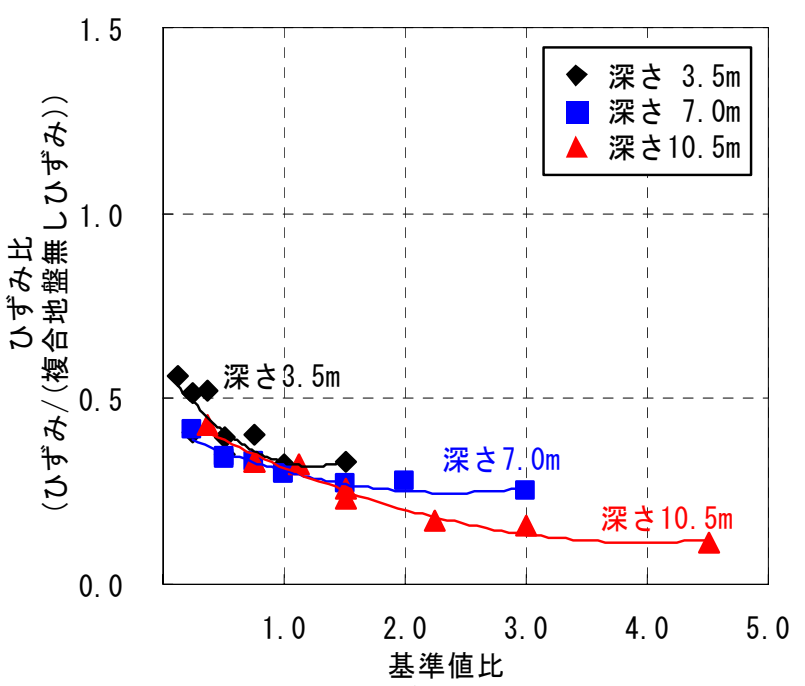

((深さ $\times$ 幅 $\times$ 強度) /(基準值 $7.0 \times 7.0 \times 400))$

図-22 杭頭の杭引張ひずみ（レベル 2 地震動）

\section{b) 複合地盤境界面の杭ひずみ}

次に, 複合地盤と未改良地盤の境界面の杭ひずみの発 現に注目した. 図-25 および図-26に，基淮值比と境界 面の杭引張ひずみの関係をレベル 1 地震動とレベル 2 地 震動に関し整理した。

レベル 1 地震動に関して, 図示した近似曲線によれば, ひずみ比は改良深さとの相関が認められる.ただし,改良 深さ $3.5 \mathrm{~m}$ でひずみ比は複合地盤無しの場合よりも増大 する結果となった. 改良深さ $10.5 \mathrm{~m}$ の場合は, 改良幅や改 良強度の増加により杭引張ひずみは減少する傾向が認め られる. また, 改良深さ $7.0 \mathrm{~m}$ では複合地盤無しの場合や 他の改良深さに比べて杭引張ひずみは大きく減少する結 果である.ただし,基準值比の影響は小さい. 


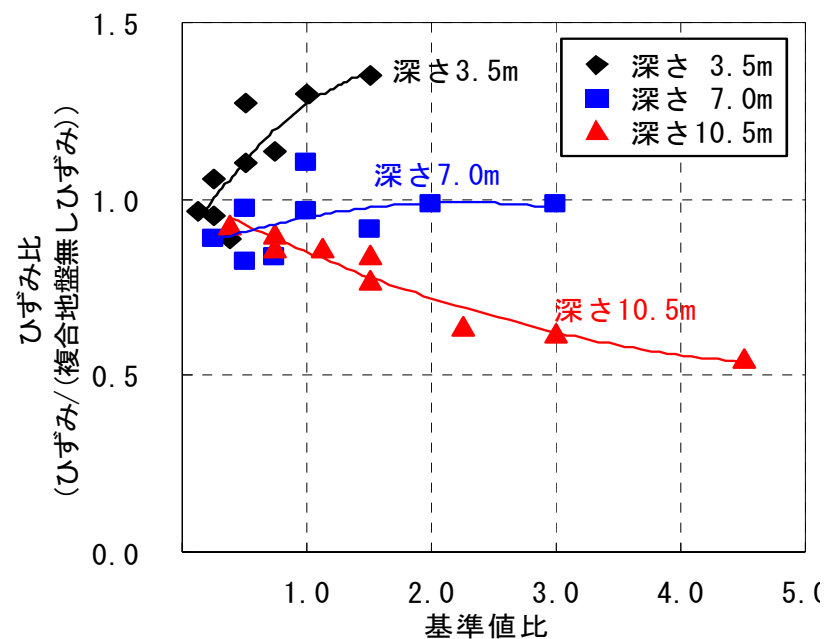

((深さ $\times$ 幅 $\times$ 強度 $) /($ 基準值 $7.0 \times 7.0 \times 400))$

図-23杭頭の杭せん断ひずみ（レベル 1 地震時）

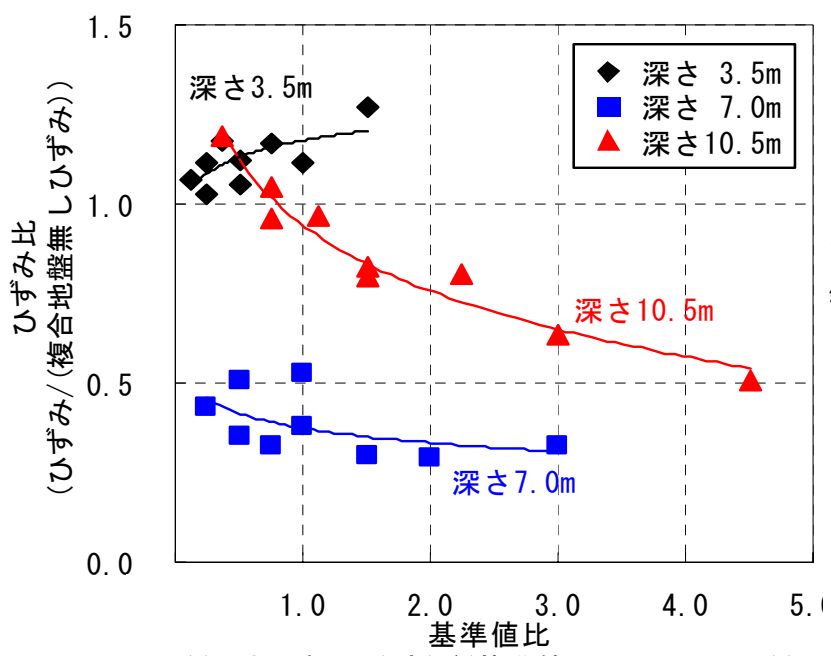

（(深さ $\times$ 幅 $\times$ 強度 $) /($ 基準值 $7.0 \times 7.0 \times 400)$ )

図-25境界面の杭引張ひずみ（レベル 1 地震時）

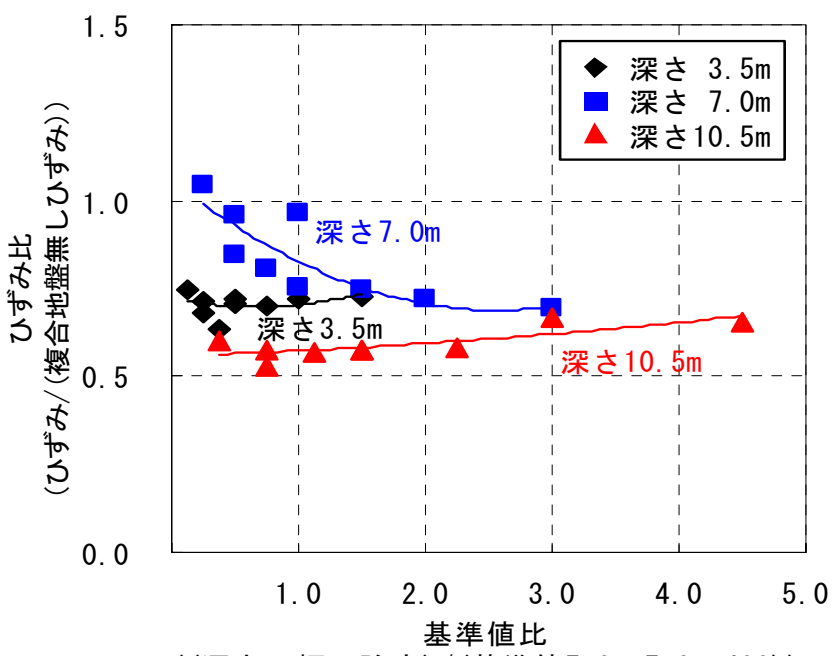

（(深さ $\times$ 幅 $\times$ 強度) /(基準值 $7.0 \times 7.0 \times 400)$ )

図-27境界面の杭せん断ひずみ（レベル 1 地震時）

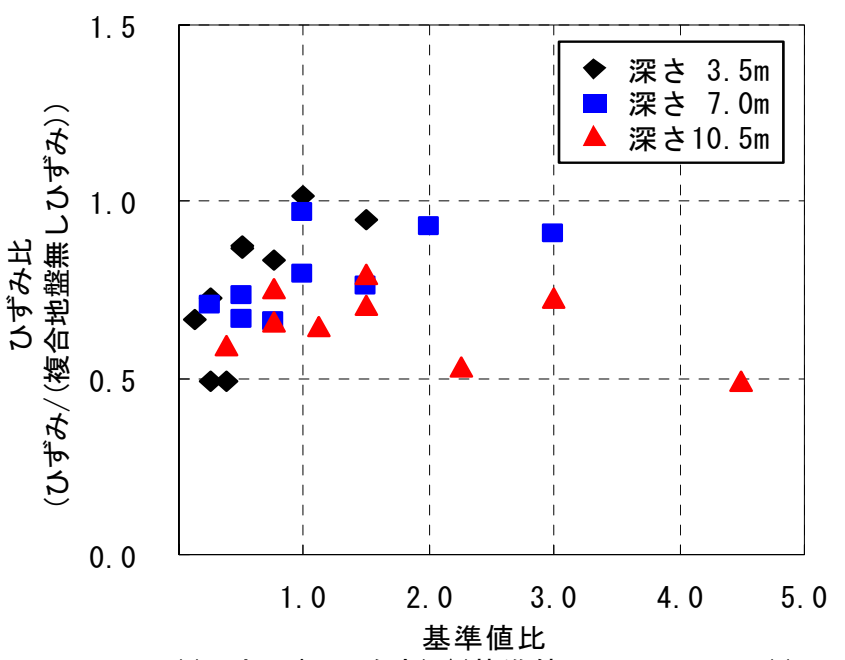

((深さ $\times$ 幅 $\times$ 強度) $/($ 基準值 $7.0 \times 7.0 \times 400)$ )

図-24杭頭の杭せん断ひずみ（レベル2 地震時）

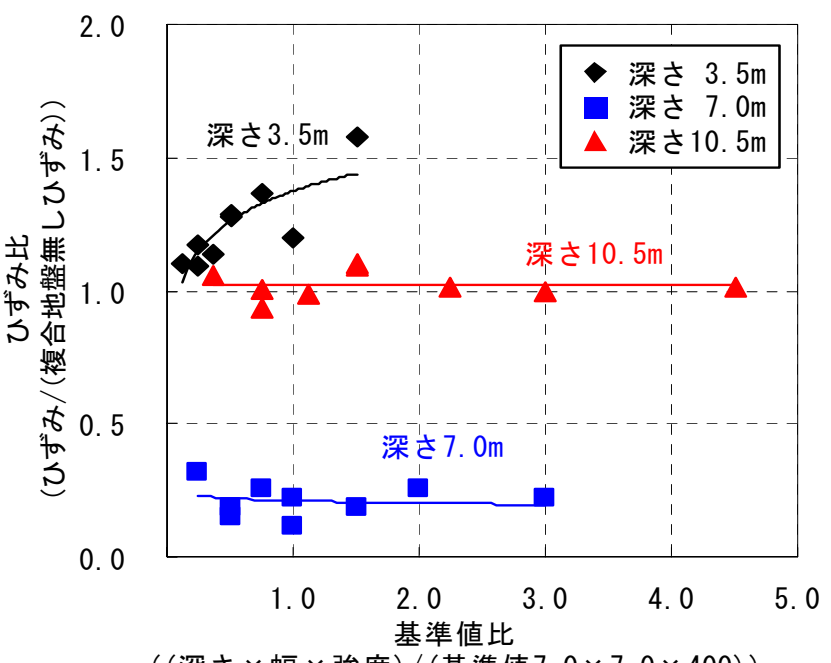

（深さ $\times$ 幅 $\times$ 強度 $) /($ 基準値 $7.0 \times 7.0 \times 400)$ )

図-26 境界面の杭引張ひずみ（レベル 2地震時）

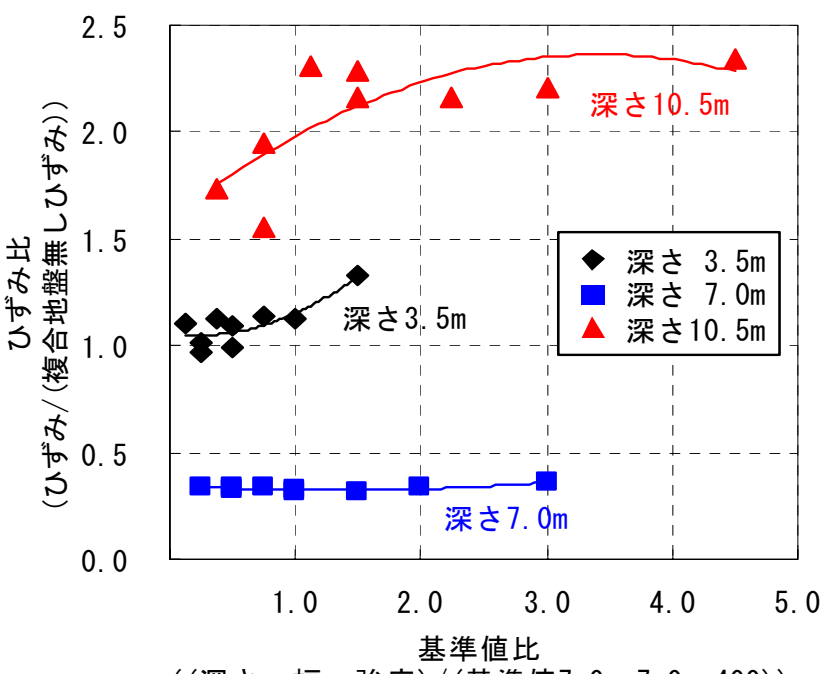

（(深さ $\times$ 幅 $\times$ 強度) /(基準值 $7.0 \times 7.0 \times 400)$ )

図-28境界面の杭せん断ひずみ（レベル 2 地震時） 
レベル 2 地震動に関しても,ひずみ比は改良深さとの 相関が認められる. 改良深さ $3.5 \mathrm{~m}$ では, ひずみ比はいず れのケースも複合地盤無しの場合よりも増大寸る結果と なった. 基準值比が小さい程ひずみ比が小さくなること から, 改良幅や改良強度が小さいほじ発生する杭引張ひ ずみは小さくなる結果となっている.これは，改良深さ が $3.5 \mathrm{~m}$ のよに浅い場合では, 境界面の杭引張ひずみを 必ずしも減少させることは出来ないことを示唆している。

また, 改良深さ $10.5 \mathrm{~m}$ の場合は複合地盤無しの場合と 大きな差異は無いが, 静的設計法で杭水平抵抗の関与範 囲とされる杭特性長 $1 / \beta$ の改良深さ $7.0 \mathrm{~m}$ の場合で, 杭引 張ひずみは大きく減少する結果となった。 これは, 複合 地盤と未改良地盤の境界面の杭引張ひずみが, 改良深さ と比例関係になく, 複合地盤における杭全体の変形モ一 ドによって左右されるためと考えられる.

次に，図-27 および図-28 に，基準值比と境界面での 杭せん断ひずみの関係をレベル 1 地震動とレベル 2 地震 動に関し示した. 図に示した近似曲線によれば,レベル 1 地震動に対し改良深さ $7.0 \mathrm{~m}$ の場合で複合地盤無しの場 合に比べて若干杭ひずみが増加するケースがあるが，総 じて杭せん断ひずみは減少している，ただし，杭ひずみ の減少傾向は改良深さと比例的な関係になく, 改良深さ $7.0 \mathrm{~m}, 3.5 \mathrm{~m}, 10.0 \mathrm{~m}$ の順で咸少度合いが大きくなっている. また, レベル 2 地震動に対しては改良深さ $7.0 \mathrm{~m} の$ 場合に, 複合地盤無しの場合に比べて杭せん断ひずみは大きく減 少する結果である.ただし,改良深さ $10.0 \mathrm{~m} の$ 場合,杭せん 断ひずみが $1.7 〜 2.4$ 倍程度に増加した. また, 改良深さ $3.5 \mathrm{~m}$ の場合は $1.0 \sim 1.4$ 倍程度に増加寸る結果となってい る.つまり, 境界面の杭ひずみは必ずしも改良深さと比例 関係になっていない.

この一つの事由として, 複合地盤と未改良地盤のせん 断岡性を対比すると, 改良深さ $10.5 \mathrm{~m} の$ 境界位置は砂碩 層であり, 複合地盤の約 4 倍のせん断岡性を有している ため, その岡性差により杭せん断ひずみが増加したため と考えられる.ただし, 改良深さが $3.5 \mathrm{~m}$ と $7.0 \mathrm{~m}$ の境界位 置は,いずれも同一の粘土質シルト層で複合地盤と約 1/2.5 の比較的小さな剛性差である.

改良深さ $7.0 \mathrm{~m}$ の場合が $3.5 \mathrm{~m}$ の場合よりも杭せん断ひ ずみが減少するのは, 複合地盤によって基礎全体に作用 するせん断力が, 結果として小さくなったためである. つまり, 複合地盤と未改良地盤の境界面の杭せん断ひず みは, 境界層の局所的なせん断岡性差に影響を受けると 考えられる.

\section{(4) 改良深さ別の地盤変形}

地震時の地盤変形の検討として, 標準的な複合地盤の パラメータを用いた場合（検討ケース 1-1）と改良深さ
を変化させた場合（検討ケース 2-1,3-1）のレベル2地震 動における地盤の最大水平変位分布を図-29, 図-30, 図-31 に示寸. 図中の赤く着色した部分は, 杭体と地盤 が剥離した領域を示寸。これによると, 改良深さが深い ほど杭と地盤の剥離領域が小さく杭周辺地盤と一体とし て挙動する傾向を示している. 改良深さ $10.5 \mathrm{~m}$ のケース で杭と地盤の剥離が生じることなく一体として挙動して いる.ただし, 7.0mのケースでは, 複合地盤と未改良地盤 の境界付近で, 他のケースに比べて地盤変位の差が大き くなっている.これは, 改良深さ $7.0 \mathrm{~m}$ の位置が $N$ 值 $=2$ の 粘土質シルト層の中間部であるため, 未改良地盤との剛 性差が影響したためと考えられる.ただし, 改良深さ位置 の $N$ 值 $=2$ であっても $3.5 \mathrm{~m}$ のースで, 複合地盤と未改 良地盤の境界で改良深さが $7.0 \mathrm{~m}$ のケースに比べて地盤 変形の差は小さい. これは, 改良深さ $3.5 \mathrm{~m}$ のケースでは 深さ方向の地盤変位が連続的で, 杭の変形に地盤の剛性 差が及ぼす影響が小さいためと考えられる.

以上のパラメトリックスタディの結果, 複合地盤のパ ラメータ（改良深さ, 改良幅, 改良強度) のうち, 地震 時の杭水平変位, 杭ひずみおよび地盤変形に最も影響を 及ぼす因子は改良深さであると判断される.すなおち, 地震時の杭水平変位および地盤変形は改良深さに伴い減 少傾向を示し, 杭ひずみは地震動の大きさに影響を受け る結果となった. これは複合地盤が深さ方向に反力体と しての効果を発揮するためと考えられる. ただし，本検 討では, 地震時の複合地盤と未改良地盤の境界面の杭引 張ひずみは, 必ずしも改良深さに比例して減少しない結 果となった. また，杭せん断ひずみは境界部の地盤性状 の影響を受けた.

以上を踏まえ, 複合地盤における杭の而震照査手法を 次節で検討する.

\section{7. 複合地盤中の杭の耐震照査フローと留意点}

一連の解析から, 複合地盤における杭の耐震設計法の 確立に向けた基礎資料が得られた。 その結果に基づき, 耐震照査フローを提案し, 耐震上の留意点を整理した. 本検討結果より, 複合地盤中の杭の地震時挙動は, 地震動 レベルの違いや杭および地盤の非線形性の影響を受け， 複合地盤のパラメータの変化により種々異なると考えら れる. また, 複合地盤と未改良部での境界面の局所的な杭 挙動も無視できない結果となった.

複合地盤中の杭の地震時挙動は, 杭一地盤系の相互作 用で決定するため非常に複雑であり, 詳細に杭の耐震性 能を検討する必要がある.

そこで, 複合地盤における杭の耐震照査フローを策定 し,図-32に示した. 照査の手順は概衫以下である. 


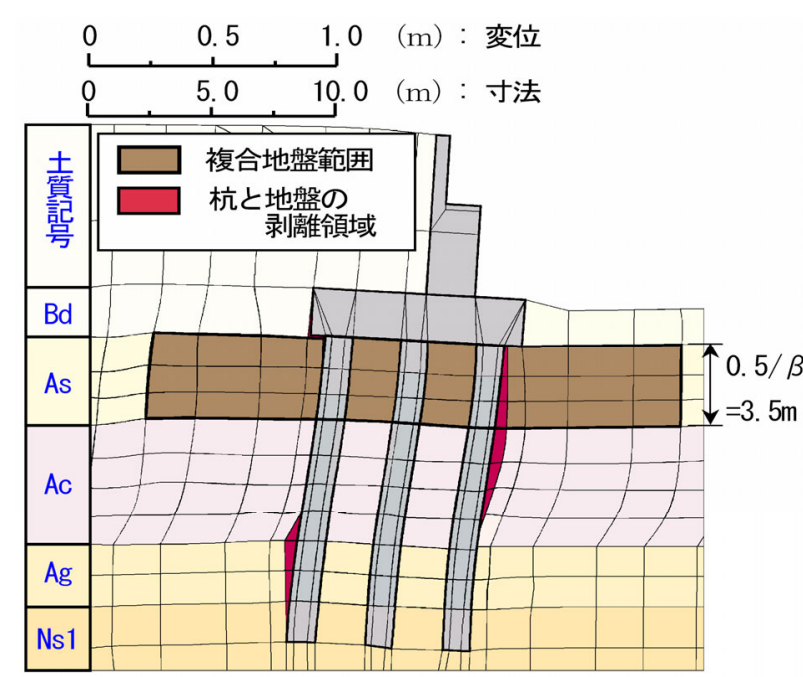

図-29 最大水平変位時の変位分布（レベル 2 地震動） (ケース 2-1：改良深さ $3.5 \mathrm{~m}$, 幅 $7.0 \mathrm{~m}$, 強度 $400 \mathrm{kN} / \mathrm{m}^{2}$ )

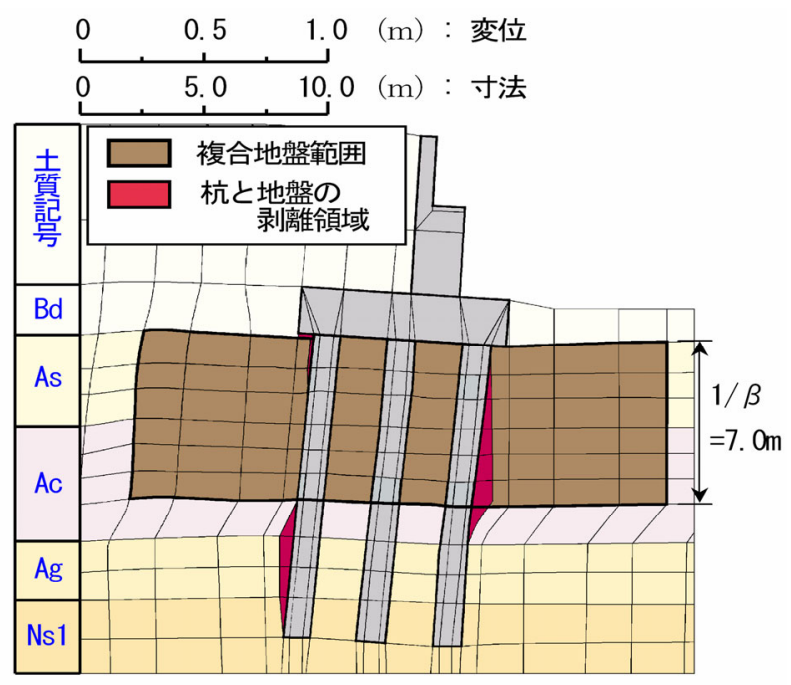

図-30 最大水平変位時の変位分布 (レベル 2 地震動) （ケース $1-1$; 改良深さ $7.0 \mathrm{~m}$, 幅 $7.0 \mathrm{~m}$, 強度 $400 \mathrm{kN} / \mathrm{m}^{2}$ )

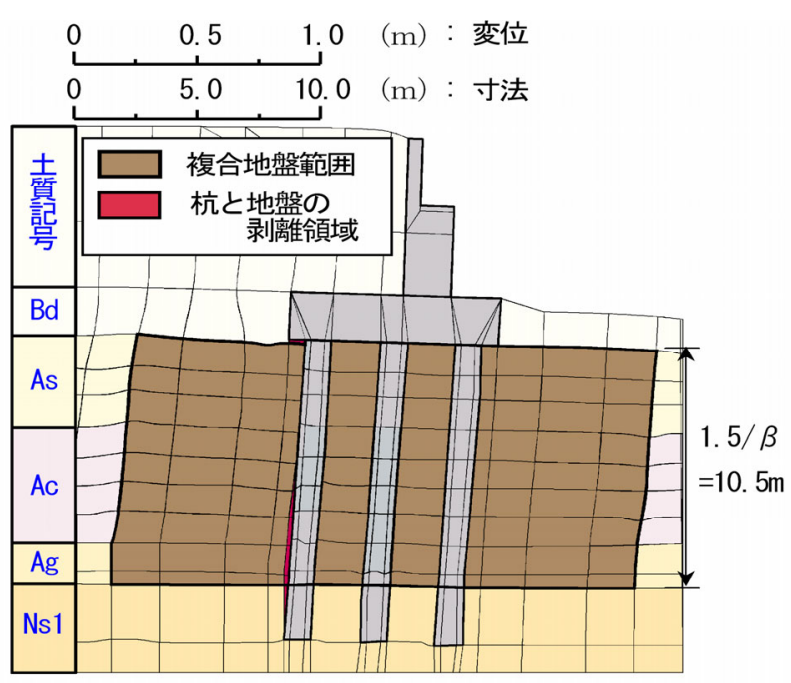

図-31 最大水平変位時の変位分布（レベル2 地震動） （ケース 3-1; 改良深さ $10.5 \mathrm{~m}$, 幅 $7.0 \mathrm{~m}$, 強度 $400 \mathrm{kN} / \mathrm{m}^{2}$ )

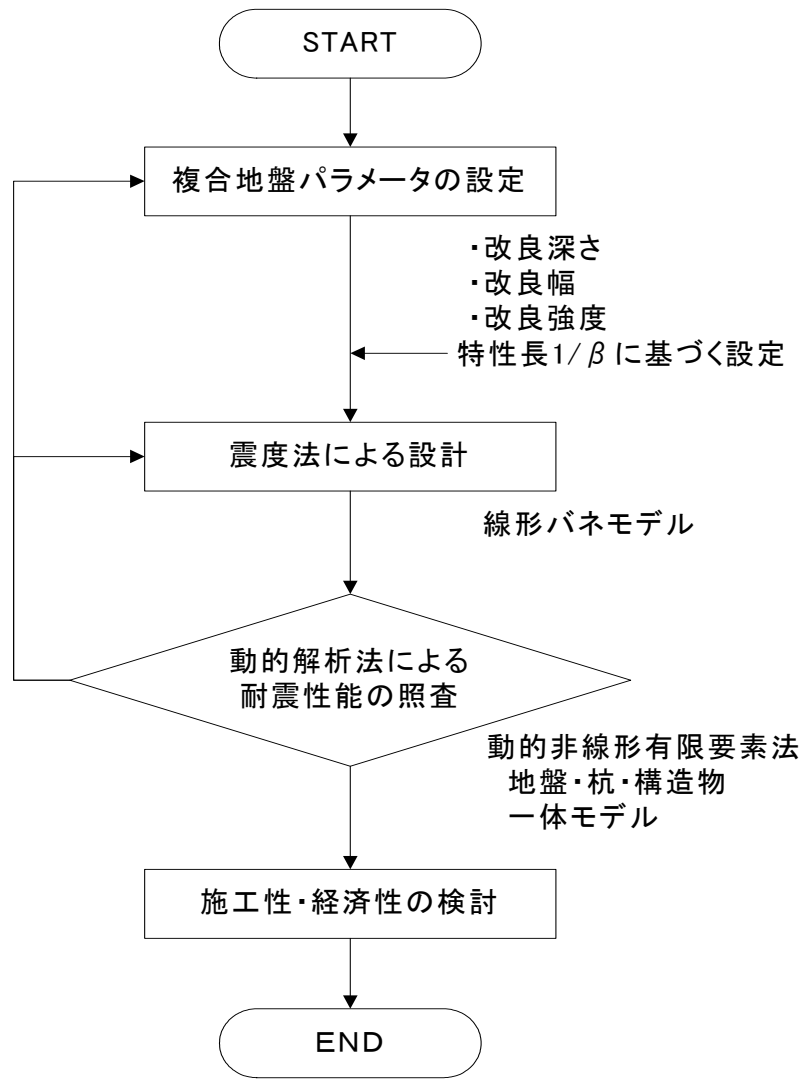

図-32＼cjkstart複合地盤における杭の而震照査フロー

(1)複合地盤のパラメータの設定

複合地盤が杭の地震時挙動に与える影響を考慮し, パ ラメータ（改良深さ，改良幅，改良強度）を設定する.

(2)震度法による杭諸元の設定 まず, 従来の震度法 ${ }^{12)}$ を基本に複合地盤中の杭諸元を 設定する.設定した杭に対し地震時の応力照查を行う.

(3) 動的有限要素法解析による而震性能の照査 震度法で設定した杭諸元に対し, 地震時保有耐力照査 法 ${ }^{12)}$ のみでなく, 地盤一杭一構造物を一体とした動的 有限要素解析法により而震性の照査をする.

その際, 複合地盤における杭の耐震照査にあたっては 以下の点に留意する必要があると考えられる.

(1) 複合地盤のパラメータの設定は, 改良深さを主要因子 とする.ただし, 地盤改良範囲は杭特性長 $1 / \beta$ を目安值 とする. その際に，現場条件に応じた施工性や経済性 についても考慮する.

(2)杭体応力照査は,杭頭部の他に, 特に複合地盤と未改良 地盤の境界面に留意する必要がある. また, 境界部の地 盤変形にも注目する.

(3) 地震動が大きくなるに従い, 複合地盤が杭に与える影 響が顕著となる. そのため, 動的有限要素法解析では, 地震動を変化させた検討を行い, その際, 杭および地盤 の非線形性についても考慮する. 


\section{8. まとめ}

本報では，複合地盤における杭の地震時挙動を2次元 動的非線形有限要素法により検討した。 その結果得られ た知見を要約し以下に示す.

1) 杭周辺に複合地盤を形成することで, 地震時の杭水平 変位, 杭ひずみ, 地盤変形が抑制される.この傾向はレ ベル 1 地震動のみでなくレベル 2 地震動においても同 様である。

2) 複合地盤の改良深さの増加に伴い, 地震時に杭水平変 位および杭体ひずみは抑制される傾向を示す.この際, 変位比の減少は複合地盤無しとの対比では, レベル 1 地震動とレベル2 地震動では異なる.これは, 主にレベ ル 1 地震動では複合地盤の岡性, レベル 2 地震動では 塑性変形の影響を受けるためと考えられる.

3) 複合地盤の改良幅と改良強度が大きくなるに従い, 地 震時の杭水平変位は減少する傾向を示寸.

4) 杭頭ひずみは複合地盤を施すことで, 地震動が大きく なるに従い減少の傾向を示す.レベル 1 地震動では改 良深さに比例的な相関を示し, レベル 2 地震動では総 じてひずみは減少した.これは, 地震動が小さい場合, 杭体は弾性挙動内にあるが, 地震動の増加に伴い複合 地盤の抑制効果が発揮されるためと考えられる.

5) 複合地盤と未改良地盤の境界面の杭引張ひずみは, レ ベル 1 地震動とレベル 2 地震動の検討では, 改良深さ に比例して減少せず, 杭特性長 $1 / \beta$ である改良深さ $7.0 \mathrm{~m}$ 場合で小さくなった.これは,複合地盤と未改良 地盤の境界面の杭引張ひずみが, 改良深さと比例関係 になく, 複合地盤中の杭全体の変形モードの影響を受 けるためと考えられる. また, 杭せん断ひずみの発現 は, 複合地盤と未改良地盤の岡性差の影響を受けるも のと考える.

6) レベル 2 地震動において, 改良深さの増加に伴い杭周 辺の地盤変形が減少し, 杭と地盤が一体として挙動す る傾向を示した.ただし,複合地盤と未改良地盤の剛性 差は, 地震時の地盤変形や杭挙動に影響を及ぼすと考 える.

以上の通り, 複合地盤が杭の地震時挙動に及ぼす影響 が概ね確認された.ただし,これらの定量は現場条件で異 なることから厳密な一般解ではない. しかしながら, 一連 の傾向には同種の工法において定性性があると考えられ る. そのため, 工法の適用に当たっては, 提案した耐震照 查フローに従い杭の而振性能を詳細に検証することが望 ましい.

\section{参考文献}

1) 冨澤幸一, 西川純一: 深層混合処理工法により形成した複合
地盤における杭設計手法, 土木学会論文集, No.799 / III-72, pp.183-193, 2005.

2) Tomisawa, K. and Nishikawa, J. : A design method concerning horizontal resistance of piles constructed in improved ground, 16th International Conference on Soil Mechanics and Geotechnical Enigineerring, pp.21872192, 2005.

3) 前田良刀, 緒方辰男, 徐光黎, 平井卓 : 地盤複合基礎の開発々 その支持力特性,土木学会論文集, No.686/VI-52,pp.91-107,2001.

4) 前中敏伸, 土屋富雄, 川崎浩司, 西崎丈能 : セメント系地盤改 良体と杭の併用基礎のモデル土槽実験, 土木学会年次学術講 演会講演概要集第3部, Vol.56, No.A,pp.706-707,2001.

5) 秋吉卓, 淵田邦彦, 松本英敏, 尻無濱昭三 : 地盤改良による杭 基礎一構造物系の而震設計について, 杭基礎の而震設計法に 関するシンポジウム論文集,pp.61-66,2001.

6) 南荘淳, 安田扶律, 藤井康男, 田蔵隆, 大槻明, 淵本正樹, 中平明 憲, 黒田兆次 : 道路橋橋脚基礎杭の地震被災解析とその対策 法に関する研究, 土木学会論文集, No.661/I-53,pp.195-210, 2000.

7) Kimura, M. and Zhang, F.: Seismic evaluations of Pile foundations with three different methods based on three-dimensional elasto-plastic finite element analysis, Soils and Foundations, Japanese Geotechnical Society, Vol.40, No.5, pp.113-132, 2000.

8) 土木学会コンクリート委員会 : 2003 年に発生した地震による コンクリート構造物の被害分析, コンクリートライブラリー $114,2004$.

9) Ashraf Shawky, 前川宏一: 経路依存性を考慮したRC／地盤系 の非線形相互作用に対する計算力学的アプローチ, 土木学会 論文集,No.532/V-30,pp.197-207, 1996.

10) Broms, B. B. : Lateral resistance of piles in cohesive soils, Proc., ASCE, Vol.90, SM(3), pp.27-63, 1964.

11) Reese, L. C., Cox, W. R. and Koop, F. D. : Analysis of laterally loaded pile in sand, Proc., Offshore Technology Conference, Houston, TX, OTC2080, 1974.

12) 日本道路協会 : 道路橋示方書 - 同解説IV下部構造編, pp.348-433, 2002.

13) 土木研究センター : 陸上工事における深層混合処理工法 設 計・施工マニュアル,pp. 48-148, 1999.

14) 北海道開発土木研究所 : 泥炭性軟弱地盤対策工マニュアル, pp.95-129, 2004.

15) 石原哲哉, 三浦房紀 : 構造物一杭一地盤系の相互作用解析に おける3次元解析と 2 次元解析との比較, 土木学会論文集, No.501 / I-29, pp.123-131, 1994.

16) 黒澤到, 福武毅芳, 藤川智, 大槻明, 宇野壽郎 : 二次元および三 次元液状化解析の比較による杭・構造物系のモデル化の検討, 第9回日本地震工学シンポジウム論文集,pp.1351-1356, 1994.

17) 杭基礎の而震設計法に関するシンポジウム論文集 土木学会 地震工学委員会杭基礎而震設計研究小委員会, 2001.

18) Maki, T., Tsuchiya, S., Watanabe, T. and Maekawa, K. : 3次元動解と2 
次元動解の比較 Seismic Response Analysis of Pile Foundation using Finite Element Method, Proceedings of the 2nd Japan-Greece Workshop on Seismic Design, Observation and Retrofit of Foundations, pp.409-416, 2007.

19) 岡村 甫, 前川宏一 : 鉄筋コンクリートの非線形解と構成則, 技報堂出版, 1991.

20) Maekawa, K., Pimanmas, A. and Okamura, H. : Nonlinear Mechanics of Reinforced Concrete, Spon Press, London, 2003.
21) 土木学会 : コンクリート標準示方書 而震性能照査編, pp.107-112,2002.

22) Ohsaki, Y. : Some Notes on Masing's law and non-linear response of soil deposits, Journal of the faculty of engineering, The university of Tokyo(B), Vol.XXXV, No.4,pp.513-536, 1980.

\section{INFLUENCE OF THE IMPROVED STRENGTH AND THE RANGE OF IMPROVEMENT OF COMPOSITE GROUND ON THE SEISMIC BEHAVIOR OF PILES}

\section{Kouichi TOMISAWA, Seiichi MIURA and Tadatomo WATANABE}

A study was conducted on the seismic behavior of piles in composite ground through non-linear dynamic analyses by using 2D FEM. As a result, displacement and strain of piles and ground deformation tended to be gorverned by the formation of composite ground. This behavior was similar under both level 1 and level 2 earthquake motions. It was also found that the influence of the improvement depth which is set as $1 / \beta$ on the displacement and strain of piles was particularly significant. Ground deformation during earthquakes tended to decrease with an increase in improvement depth. Based on these findings, a seismic design method adequate for such piles was proposed and seismic issues were reviewed. 